Historic, Archive Document

Do not assume content reflects current scientific knowledge, policies, or practices. 


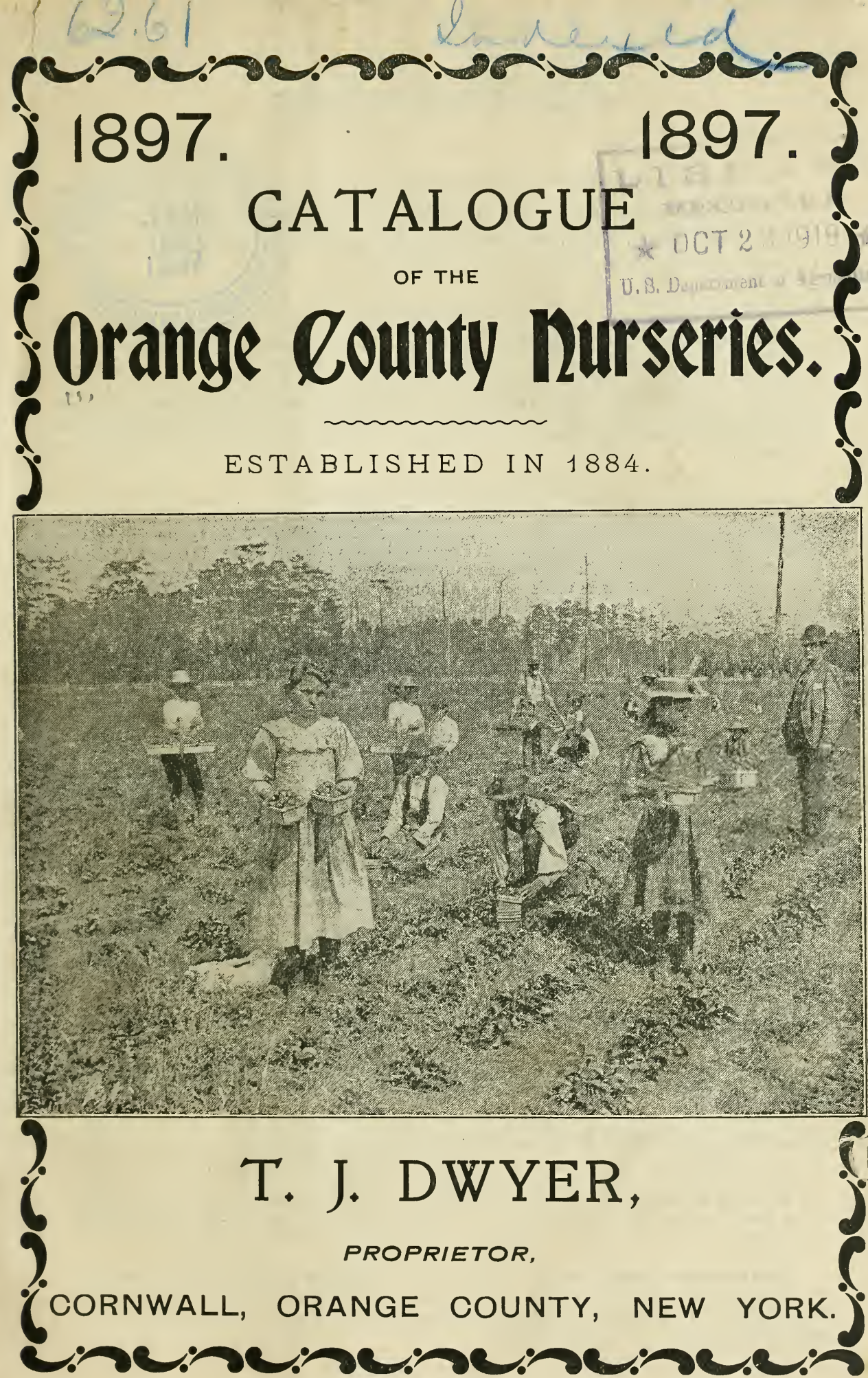

DAILY NEWS PRINT, NEWBURGH, N. Y.-1-5-87-12,500. 
As to our responsibility and good standing we refer to Mr. C. L. C. Kerr, cashier of the National Bank of Newburgh, at Newburgh, N. Y., the Cornwall Savings Bank, Cornwall-on-Hudson, N. Y., the Postmasters at Cornwall, Cornwall-on-Hudson and Cornwall Landing, or any business firm of this place.

\section{[From Rural New Yorker.]}

We have just received a copy of the summer and autumn catalogue of the Orange County Nurseries. Mr. T. J. Dwyer, the proprietor, is one of those hardworking, industrious men whose merited prosperity we are always glad to recognize, and has been attained by hard work, scrupulous care in business and a name of which any man may well be proud. The new catalogue is well illustrated and we suppose will be sent free on application. Purchasers will find the goods as represented.

\section{[From New York Farmer.]}

The illustrated and descriptive spring Catalogue of the Orange County Nurseries, sent out this season by T. J. Dwyer, of Cornwall, N. Y., is the finest yet issued by this popular nurseryman. It contains about 70 well printed pages, descriptive of the stock to be found at these nurseries, and all who ever had dealings with Mr. Dwyer know that he is most conscientious in his recommendations and dealings.

\section{[From New England Homestead.]}

Mr. T. J. Dwyer, of Cornwall, N. Y., is a practical nurseyman, and has earned a reputation for sending out nothing but first-class stock. In his advertisement on another page he offers to send his spring Catalogue free on application.

Our Splendid Location makes our shipping facilities unsurpassed. Cornwall, N. Y., is situated on the west bank of the Hudson River, about fifty miles from N. Y. City, five miles from West Point, and ninety miles from Albany, the State Capital.

Three railroads run through the place, the West Shore, Erie, and Ontario and Western, and the N. Y. C. \& H. R. R. is across the Hudson River. We can connect with this road at Newburgh, which is only four miles from Cornwall.

We can ship by Freight with any of the railroads named above, and by the Ramsdell Transportation Co. (boats) to New York City, by the Albany line of boats, the Kingston line of boats. Other passenger boats (which do not carry freight), among them the Mary Powell, land here also.

We can forward by Express by the National, American, Adams, and Wells, Fargo \& Co. Express Companies.

We are only one and one-half miles from all these means of transportation. You can readily see that our shipping facilities are unsurpassed.

The fare is only twenty-five cents to the Nurseries from the West shore Depot, Ontario and Western Depot, from all the boat landings named above. Stages meet all trains and boats,

Our Telegraph Office is Cornwall-on-Hudson, N. Y., less than one mile from our office. All messages will reach us promptly after being received here.

Special Notice.-We are pleased to announce that we have secured a reduction of 20 per cent. on the express rates on plants; this will be a great saving to our customers.

You can save ten per cent. We will also allow you a discount of ro per cent. on any order to the amount of $\$ 1.00$ and upward, provided the same reaches us before March 15th. (We cannot allow this discount on the Family Lists named in this catalogue.) 


\section{GENERAL INSTRUCTIONS.}

Please remember that remittance by money order, postal note and registered letter should be made to us at Cornwall, N. Y. Remittance may also be made by express money order, which to many is a very convenient way to send money.

Payments.-Unless otherwise agreed, payments must be made in advance. Goods sent C. O. D. when one-third the amount is sent with the order. Prices in this catalogue abrogate all previous quotations. Fifty, five hundred and one-half dozen of a variety will be furnished at the one-hundred, one-thousand and dozen rates respectively.

Our Guarantee.-While we exercise the greatest care to have all our trees, vines and plants true to label, and hold ourselves ready on proper proof to replace any stock that may not prove true to label, free of charge, or refund the amount paid for such stock, it is mutually understood and agreed between the purchasers and ourselves that our guarantee in no cast makes us liable for any sum greater than the amount originally received for such stock that proves untrue.

Terms Cash.-Orders from unknown persons must be accompanied by a draft on New York, registered letter, postal note or money order on Cornwali, N. Y., or reference that will be satisfactory.

Orders.-Please write orders on separate sheet, apart from the body of the letter, and be very particular to give the name and address distinctly, and thus aid us to facilitate execution and prevent errors.

Order Early. - Please send in your order as early as you can, the earlier the better. In the busy season all are treated alike and must wait for their turn. Do not wait until late in the season, when the stock has started to grow, and will be more or less injured by removal. Our old customers know that they can send in their orders any time, and we will forward it at any date they name. Parties unknown to us can place their orders early in the season by remitting fifteen per cent. of the amount of order, and the balance when they wish the stock shipped.

Our Prices are as low as anyone can grow and pack good, strong, healthy stock for. If, however, you wish to purchase a large order of goods, please send us your list, and we will furnish you a special low figure on it.

Packing.- No charge is made for packıng or for delivering to freight depots or express offices here.

Shipping.-Plain and explicit shipping directions should be given with every order, naming mode and route for forwarding, otherwise we will use our own judgment; but, upon delivery to railroad, steamboat or express companies, our responsibility ceases, and they alone must be held accountable for loss or delay.

You can save ten per cent.-We will allow you a discount of ten per cent. on anv order to the amount of $\$ 1$. Oo and upward, providing the same reaches us before March I5th. (Family Lists excepted.)

Plants by Mail.-Strawberries, Raspberries, Blackberries and Grapes can be sent by mail at the following rates, in addition to prices named :

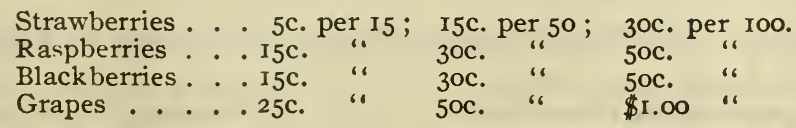

Address T. J. DWYER, 


\section{FAMILY LISTS.}

$\Phi$

$\mathrm{HE}$ desirable lists named below are offered at a much reduced price, and we hope many will avail themselves of these liberal offers. Any information desired as to the variety of fruits offered may be found in this catalogue under the proper heading.

We can send any of the following collections by mail postpaid for $\$ 1 . \infty$. We cannot allow any discount from these lists.

\section{$\$ 1.00$ MAIL LISTS.}

List 1.

12 Brandywine Strawberry.

If Marshall Strawberry.

I2. Michel's Early Strawberry.

I2 Parker Earle Strawberry.

I2 Lovett's Early Strawberry.

List 3.

6 Erie Blackberry.

6 Loudon Raspberry.

6 Miller Raspberry.

3 Industry Gooseberry.
List 2.

6 Fay's Prolific Currant.

6 White Grape Currant.

6 Lee's Prolific Currant.

6 Red Dutch Currant.

List 4.

Early Ohio Grape.

I Alice Grape.

I Green Mnuntain Grape.

I Moore's Early Grape.

3 Columbian Raspberry.

\section{FAMILY LISTS BY EXPRESS OR FREIGHT.}

\section{(Purchaser to pay transportation charges.)}

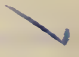

List 5.-For \$2.50. Pot Grown Strawberry Plants.

25 Marshall, 25 Brandywine, 25 Parker Earle, 25 C. Triumph. Please note that these are all Pot grown plants and will bear fruit the coming season.

\section{List 6. For $\$ 7.50$.}

All strong, pot-grown plants, and desirable for all who wish a fine crop of the best fruit grown in a short time from planting. Please consider this offer well, as it is one of the best we have ever made.

Ioo Brandywine, Ioo Marshall, Ioo Parker Earle, roo Bubach. If planted early in good ground the above plants will furnish an ordinary family with fruit for their table during the coming season. We can ship pot-grown plants most any time.

\section{No. 7.-List of Good Peaches, Plums and Quinces for \$3.00.}

2 Wonderful Peach, yellow.

2 Keyport White Peach, late.

2 Hale's Early Peach medium.

2 Stephen's Rareripe Peach, late.

2 Chinese Blood Peach, red.
Spaulding Plum, yellow.

I Abundance Plum, early.

I Lnmbard Plum, red.

I Meech's Prolific Quince.

I Rea's Mammoth Quince. 


\section{No. 8. - List of splendid Apples, Pears and Cherries for \$3.00.}

I Red Astrachan Apple, early.

I Yellow Transparent Apple, early.

I Gravenstein Apple, Fall.

I Fall Pippin Apple, Fall.

I Baldwin Apple, Winter.

I King Apple, Winter.

I Lawyer Apple, Winter.

I Lady Elgin (Crab) Apple.

$V_{\text {I }}$ Bartlett Pear, early.

I Seckel Pear, second early.

I Sheldon Pear, late Winter.

I Anjou Pear, late Winter.

I Black Tartarian Cherry.

I Napoleon B. Cherry, white.

I English Morello Cherry, late.

The prices asked for above lists include packing in a thorough manner, and are for No. I, selected trees and plants. We cannot make any discounts from these lists.

\section{STRAWBERRIES.}

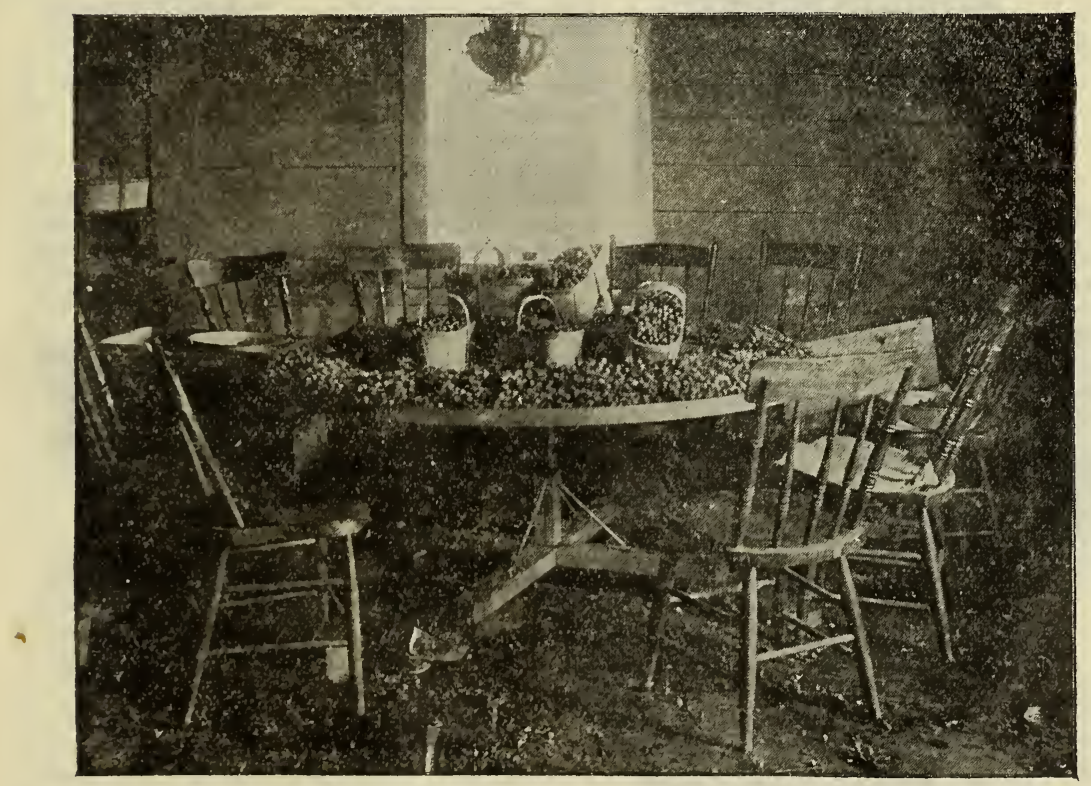

HOW TO PLANT.

Land that has been previously cropped with wheat, corn, potatoes cr cabbage, is well

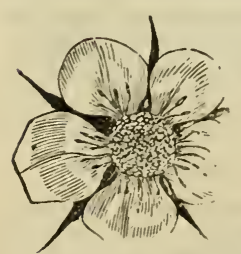
adapted for a strawherry plantation, providing it is well manured, ploughed deep, thoroughly harrowed and put in first-class condition, and above all, that water does not remain on the ground any length of time after a rain. This would be ruinous to them, particularly in the fall and spring months, when the ground freezes and thaws at intervals. Our experience has been that while some varieties fail entirely on light soil, yet the varieties that succeed on light soil inPERFECT FLOWER. variably improve on heavy land, providing, of

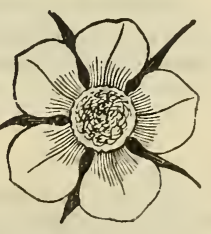

PISTILLATE. 
course, it does not bake. After the arrival of the plants, unpack them, and loosen the

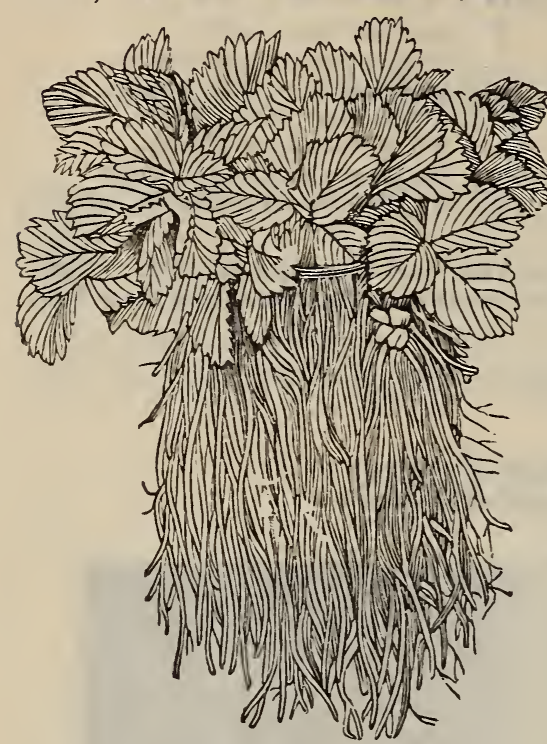
bunches. Prepare a muddle composed of tine manure and water. Dip the roots of the plants in it, and be sure that all the roots are moistened. Heel them in the ground near where

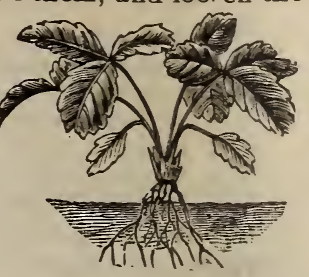
you are to plant STRAWBERRY PLANTED them, and if the sun is very warm cover the leaves with hay, straw or sea grass. Avoid planting on awindy day; ten minutes' wind is worse on the roots of plants than one hour's sun. Only drop a few of the plants in advance of the planter. Set the plants not less than TOO SHALLOW.

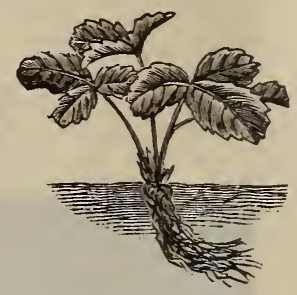

WRONG WAY OF PLANTING.

BUNCH OF STRAWBERRT PLANTS.

three feet apart between the rows, and twelve inches in the rows. Set the plant $s_{0}$ that the crown shows over the surface. Plant the pistillate varieties between the perfect-flowering kind, having a row of the perfect varieties to every third row of the imperfect varieties. If you are planting in a large way, make a furrow some six inches deep. and set the roots in it straight down. Draw the soil around the plants with the hands, and so firm the soil around them that the leaf of the plants will break in two before the

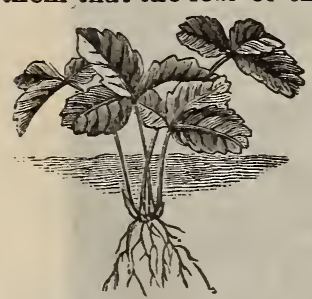

STRAWERRY PLANTED TOO DEEP. plants will allow themselves to leave their places. The remainder of the furrow can be readily leveled in with the hoe. If you have only a family bed to set, draw a straight line and use the garden trowel to make place for the plants, and firm the ground around ihem with the hands and weight of the body, thus you will always leave the ground level around them. Should the ground be dry, or the sun very warm, use any mulching material

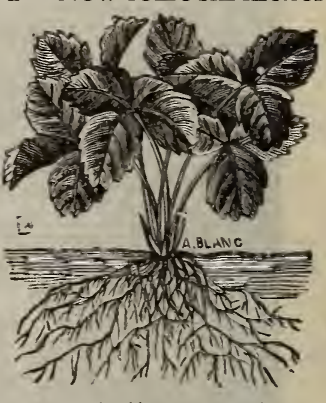

RIGHT WAY OF PLANTING. at hand (that will admit of light and air) to shade the plants for a few days, or until you have rain. To set an acre of plants, one foot apart in the row and three feet apart between the rows, would require Io,000 plants.

We have thirteen acres in Strawberries, all used for propagating purposes.

We have a fine large stock of all the good varieties, and would ask for an opportunity to figure on any large lot of plants. We can furnish you at low prices, in quantities of 5,000 , 10,100 or 20,000 , and request you to mail a list of your wants.

\section{T. J. DWYER,}

Circleville, N. Y., Match I0, I8g6.

Dear Sir-I euclose order and $\$ 3.00$ for pot grown strawherry plants if thev prove to be as good as the raspherries and black caps I obtained of you. I will be more than pleased. They were a wonder and delight to all, through the bearing season last summer; with best wishes. Respectfully yours, 


\section{POT GROWN PLANTS.}

30 We beg to call your special attention to our fine list of pot-grown strawberry plants. The plants are strong and vigorous, and if planted in good, rich soil in the early Spring, will produce a nice lot of haudsome large fruit the coming June.

Please Note. - That all varieties not marked (Pistillate) are perfect flowering kinds, and can be planted without planting other sorts with or near them. Also note that it is the reverse with the Pistillate varieties, and that it is absolutely necessary that they should be planted near the perfect flowering kinds. I have known of many failures and serious losses caused by the planting of imperfect varieties, and not properly fertilizing them with the staminate fruits.

\section{SOME GOOD NEW VARIETIES.}

Marshall (Perfect Flowers).-The Marshall is positively the strongest grower of any strawberry we have ever tested. I may be mistaken, but I feel assured that this berry has a great future, especially in the home garden and for fancy market. It comes nearer the ideal strawberry than anything else I have yet seen. It is beyond cloubt one of the largest (probably the largest) berry yet introduced; the plants are the rankest growers; away ahead of all others in this respect. In shape conical, very regular, each berry like the other; the color is a dark red crimson; the flesh is solid and dark red; the flavor is the very finest. It is possible to ship this berry hundreds of miles. It ripens in mid-season and continues in bearing until very late in the season.

The above is from our 1896 catalogue. Now, after another year, we are ahle to affirm what we then wrote. We fruited the Marshall quite largely last season. It gare us berries for our own table for 26 days. All who saw the Marshall in fruit on our grounds were of one opinion-that it was the largest and best flavored strawberry they had ever seen. The writer would go farther. and say that of the several

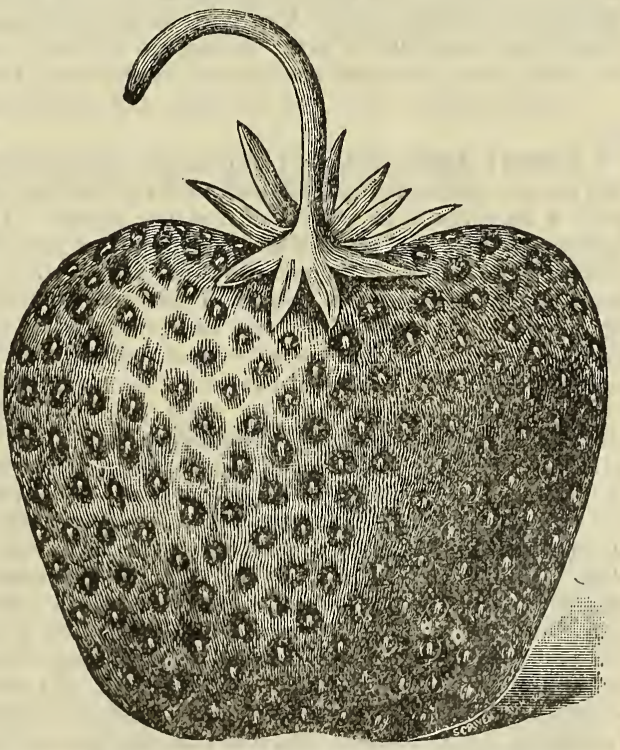

MARSHALL. hundred varieties he has known and is familiar with, not one pleases him as well as the Marshall. We have been recommending the Marshall to all, either for the home use or for market purpnses. Our stock of this grand berry is large and fine, and we will make the price as low as we possibly can for good, strong, well grown plants.

Please remember that the plants we offer for sale are grown in beds that have never borne fruit which makes them worth considerable more than the ordinary plants.

Price per doz. $25 \mathrm{c}$., per $10075 \mathrm{c}$., per $1000 \$ 5.00$. 


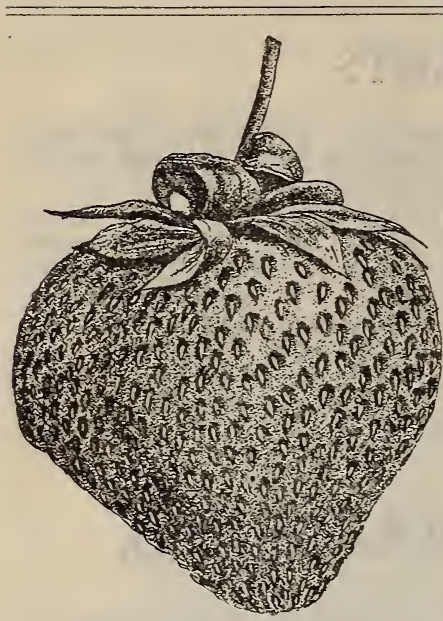

BRANDYWINE.

Brandywine.-We give this berry second place on our list and believe that it has a great future. The plants are very large; in fact, it is hard to decide which is the strongest grower this plant ur the Marshall. The Brandywine has perfect flowers, fruit of immense size and fine quality, firm and shapely for so large a berry, foliage of the largest and thriftiest, entirely free of scald or blemish, Heavy peduncles. The average size is as large as any ever raised, and the shape is more uniformily good than that of any other of the largest varieties. In general it is heart shape, often broadly so without neck. Its most pronounced irregularity inclines towards a Sharpless shape, occasionally as of two berries joined together. Calyx and Sepal broad, and many medium red, flesh red, firm and solid for so large a berry, none more so, quality not the best, but fully as good as Sharpless, and better than Bubach. Vines exceedingly prolific. Brandywine continues a long time in fruit, and is of a superior shape, quality and size for so large a berry. It ripens in mid-season and continues in bearing late in the season, a very profitable variety and one that is being planted largely. The plants we offer for sale of this variety (as well as of all others) are propagated from plants that have never been permitted to bear-you can readily see that these plants are strong and vigorous aud worth much more than the usual run of plants.

Price per doz. $25 \mathrm{c}$., per $10075 \mathrm{c}$, , per $1000 \$ 4.00$.

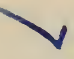

Parker Earle (Perfect Flowers). -The plants if this variety are exceedingly rank and vigorous growers, with a tendency to make enormous stools. It has perfect flowers and good sized fruit, rather long, with a short neck, firm, of good color and fine quality. We have heard nothing but words of praise for the Parker Earle. It is one of the few varieties that is adaptable to a wide range of country, and thrives well in so many different soils and climates. We are fruiting it on four separate soils, and in each it is a wonder of productiveness. We have counted as many as three hundred and fifty berries and blossoms on single plants in our trial beds and in other parts of our nursery. Let it be understood that the Parker Earle plants are among the few strong growers we have, and are fully able to mature all the fruit set. A great many are under the impression that the Parker Earle is an early berry, and it is quite a common occurrence to have the plants called Parker Early instead of Parker Earle. It is not by any means an early berry, not even a second early, or mid-season fruit. Ripening quite late in the season, it should be known as a late berry. No one can make a mistake by planting this grand variety.

Price per doz. 25c., per $10075 \mathrm{c}$., per $1000 \$ 4.00$.

T. J. DWYFR. F,sQ.

BEEDES, N Y., Aug. 15, I8g6. Dear Sir-The strawberry plants you sent me arrived in fine condition, and about 20 per cent.
orer count ordered.
The transplanter arrived yesterday and I was surprised to hnd how well it worked even in our
leaf mould soil.

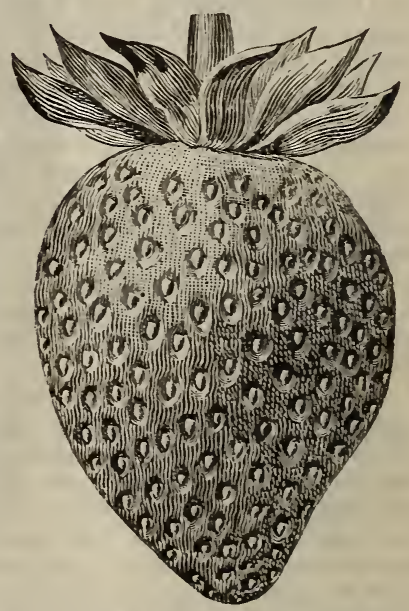




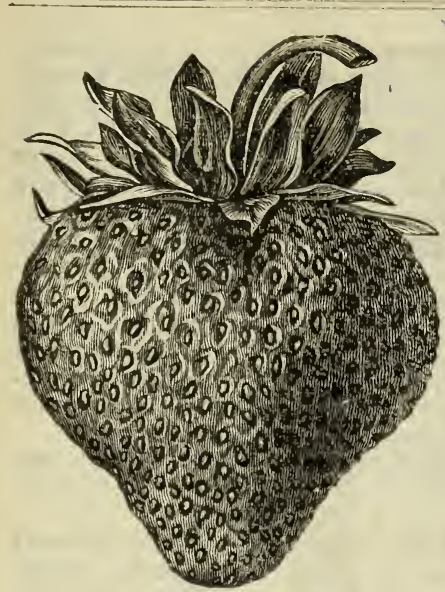

Greenville (Pistillate).- We are very well pleased with this new berry. We have found the plants good, strong, clean, healthy growers, with a compact, dark, rich foliage, resembling the Bubach in niany respects. The fruit, however, is finer and of much better flavor. It is large, firm, dark crimson in color, quite regular in shape and even in size, and ripens evenly all over. It is very productive, and ripens in mid-season. The plants thrive well, wherever we have heard from them. The Greenville is to-day a very popular new variety.

The above is taken from our 1896 Spring catalogue. Last season's fruiting of the Greenville confirms our opinion of its real merit. We believe this berry has come to stay.

Price per doz. 25 c., per $10075 \mathrm{c}$., per $1000 \$ 4.00$.

You Can Save Ten Per Cent.-We will allow you a discount of ten per cent. on any order to the amount of $\$ 1.00$ and upwards, providing the same reaches us before March 15 th. (We cannot allow this discount on the family lists named in this catalogue.)

\section{SOME OF THE NEWER VARIETIES.}

W $m$ Belt (Introducer's description.)-The plant is very large, a most luxuriant grower, and remarkably productive. At the end of last year's drougth, early in November, it was not surpassed for green, healthy appearance by any one of over roo varieties on my place. Its blossoms are perfect, and it setms that each one is followed by a berry. It is medium in ripening - neither very early nor very late. Its size is very large indeed. No other variety ever gave me so many immense berries. In picking twelve quarts from a matted row with good conımon culture, I selected thirtyseven that filled three quart baskets, and the other nine quarts were all large. I have seen eight. inch berries on spring set plants within ten weeks of planting. In form it is conical, rather long and quite uniform in shape, except that the first berry on a fruit stalk is some times misshapen, especially with high culture. The color is a brilliant, glossy red-as near perfection as was ever seen in a berry. It ripens all over without green tips. The quality is good.-better than is usually found in large berries.

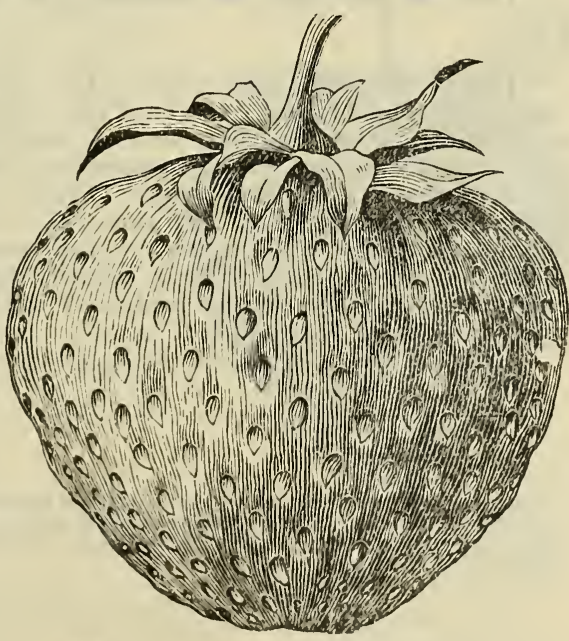

Price per doz. $40 c$., per $100 \$ 1.00$, per $1000 \$ 7.00$.

T. J. DWYER, EsQ. Cornwall, New York.

Ballardvale, Mass., April I5, 1896.

Dear Sir-The Currants and the Blackberries arrived; am much pleased with them.

Yours truly,

C. H. MARLAND. 


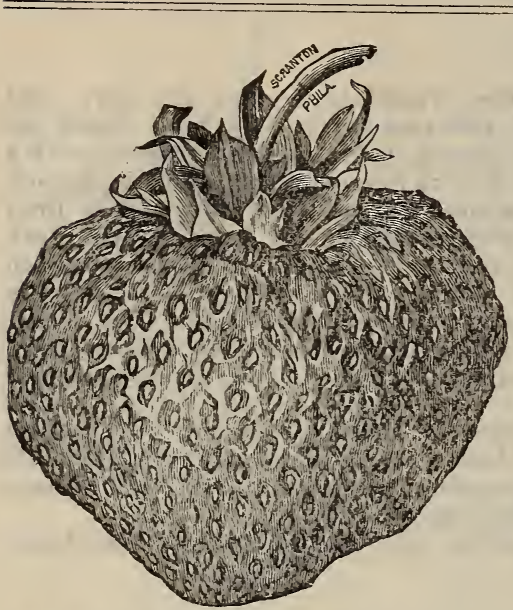

Enormous (Pistillate). - A new variety from Illinois that seems to be well named, since it is remarkable for its immense size. In general appearance it somewhat resembles Bubach No. 5, but the plant is a better grower and the fruit is larger and very much firmer. Often variable in shape, deep crimson, very glossy, firm and solid; quality very good indeed. It is excellent for canning, retaining its form perfectly. The plant is a strong grower and abundant bearer, its foliage showing not the slightest sign of rust. It has given immense satisfaction wherever fruited and will undoubtedly take a high rank. Early in ripening. $\$ 8.00$.

Price per doz. 5 Oc., I00 $\$ 1.00$, per 1000

Glen Mary (Perfect Flowers).-As to its immense size the Rural New Yorker speaks as follows: "Glen Mary received from E..T.

Ingram, April, I894, June 7, 1895, largest ripe berries up to date. Good shape for so large a berry. June gth, berries very large, firm enough for a near market, about the shape of Sharpless. June IIth, large to very large. June I4th, a large yielder of large berries of good form, broad heart shaped, often widening at the tip, one of the most promising of our latter trials. June I 7 th, past its best. June 18th, still bearing a good many berries which hold their size unusually well. June 2Ist, still in bearing. Many of the berries are of the largest size." $\$ 20.00$.

Price per doz. $75 \mathrm{c}$., per $100 \$ 3.00$, per 1000

Jersey Market (Pistillate).-The introducer has this to say of it: "The berries are bright crimson in color and of large but not mammoth size; being remarkably uniform in both size and color. They are above the average in firmness, of rich, delicious quality and ripen in midseason. Plant of exceptionally strong, healthy habit

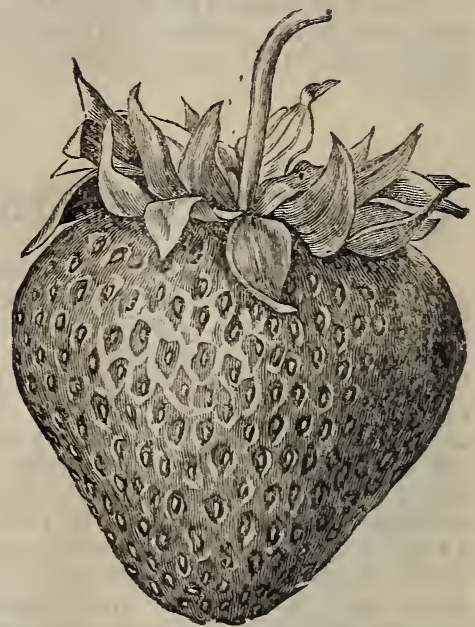
and a heavy reliable yielder under all conditions-one that everybody can depend upon and not be disappointed."

Price per dozen, $\$ 1.25 ; \$ 100, \$ 7.00$.

MR. T. J. DWYER,

Hamiltow, Bermuda, Nov, izth

Dear Sir-I received your letter and two boxes of strawberry plants. They arrived in capital condition. I enclose you a $\$ 20$ note; please send me by return, 2,000 more strawberry plants, I00 raspberry plants. As trial send which you think suitable for this climate, one dozen dewberries and one dozen wineberries.

Yours truly,

RICHARD KEMPE.

T. J. DWYER, ESo.,

5I River Street. Troy, N. Y., May 22nd, I895.

Dear Sir-My brother either wired you or wrote you from Berlin to ship at once to me at Berlin, $N$. Y., one thousand Lovett's strawberry plants. which makes 18000 ordered from you this spring. I wish to say to you that my brother says, of all the strawberry plants we have received, vours were ahead of anything. they being excellent plants, and arriving in good condition, and I wish to compliment you upon the same,

Yours truly, 
Michigan (Perfect Flowers).-The introducer has this to say of the Michigan: "It is not only a handsome berry and firm, equaling in size the Gandy, of high quality, but ripens ten days to two weeks later than that superb strawberry-in fact, when Gandy is at its best, the Michigan begins to show color upon its first ripening berries. In form it is bluntly conic, exceptionally uniform in size and shape, and of briglit crimson color, with distinct yellow seeds. The plant is a strong, healthy grower, and very prolific."

Price perdoz. 50c.; 100 $\$ 2.00 ;$ I, 000 $\$ 15.00$.

Anna Kennedy (Pistillate)-It is extremely sturdy and vigorous. But the fruit is what is truly wonderful. The almost globular berries are as smooth and regular as though moulded. Of the

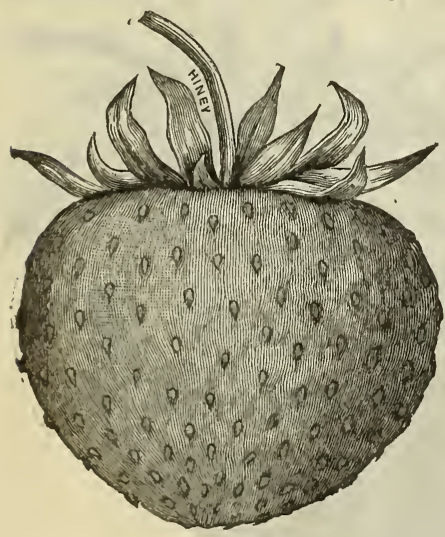

ANNA KENNEDY. most intensely brilliant flame color imaginable

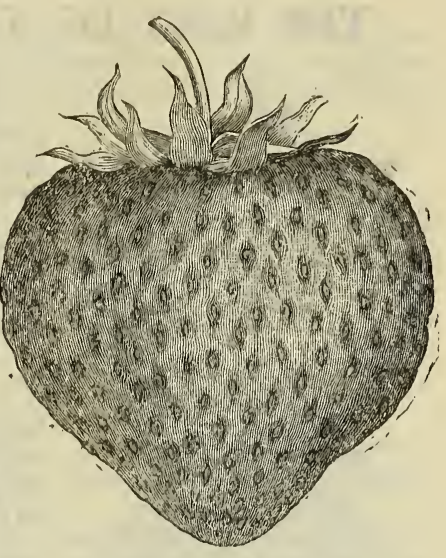

MICHIGAN. and so glossy that the light plays upon them and is reflected as with jewels. During the ten years we have Iruited this variety, we have yet to find a cockscombed or ill-formed berry. In addition to its marvelous beauty it is extremely rich, sweet and sprightly, medium to large in size, and firm.

Price per doz. $50 c$.; $100 \$ 2.00$; $1000 \$ 15.00$.

Eleanor (Perfect Flowers).-The introducer's description: "The Eleanor is second to none in earliest ripening with Crystal City, and in advance of all others. In size rivaling the Sharpless, retaining its size well to the end of the season. In productiveness surpassing the famous Crescent, in firmness equal to the Wilson, is of bright scar et color and has few equals in quality." The plants are said to be exceptionally strong growers. Eleanor has not fruited at the Orange County Nurseries as ret. Will have it in fruit the coming season; the plants are very small; it may be very early, but we have but little hope of its rivaling the Sharpless in size.

Price doz. 30c.; $10075 \mathrm{c}$.; 1,000 $\$ 4.00$.

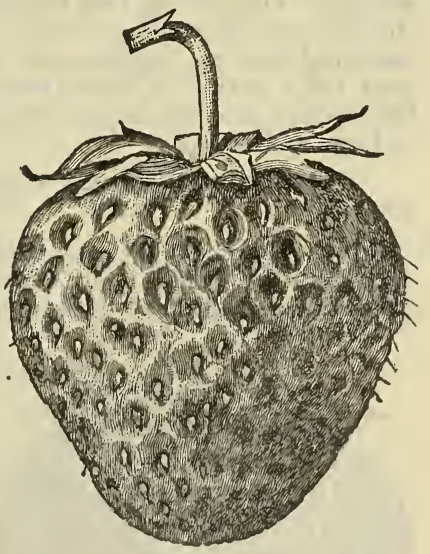

ELEATUR.

Mr. T. J. DWyer, Orange County Nurseries. Cornwall, New York,

Clinton, N. Y., Aug. 5, 1896. The strawberry plants reached me in fine condition. Thank you for the generous allowance. Yours truly,

M. L. RANDOLPH.

Mr. T. J. DWYer, Cornwall, N. Y.,

Brookside, Morris Co., N. J., Nov. II, 1895.

Dear Sir-Please send catalogue of plants. The asparagus roots and trees bought of you last Spring came in first-class order and are growing nicely; all the other berry plants are growing elegantly. 


\section{THE BEST OF THE STANDARD VARIETIES.}

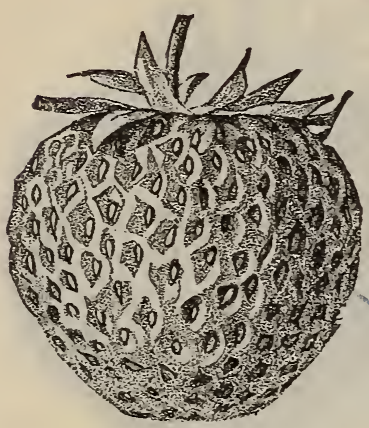

MICHEL'S EARLY.

Michel's Early (Perfect Flowers).-The Michel is a perfect flowering sort, an extra early fruiter. Berries of good size, immensely productive, a good market berry, and, all things considered, a very profitable extra earIy berry.

This variety has become very popular for the last two years. There is no doubt but what it is one of the most profitable extra early varieties. We have received as high as 25 cents per quart for this fruit the past two seasons.

Price per doz. 25c., per $10060 c$., per $1000 \$ 3.00$.

Lovett's Early (Perfect Flowers).-Lovett's Early is a perfect flowering variety, prolific, and a good market berry. It averages larger than the old Downing. resembling that berry in shape, color and flavor. We have planted very largely of this berry, and recommend it as a good. profitable fruit. It ripens with the mid-seasnn berries, and is one of the most profitable market berries we have.

Price per doz. 25c., per $10060 \mathrm{c}$, , per $1000 \$ 3.00$.

Cumberland Triumph (Perfect Flowers) - It has a fine healthy foliage. The fruit is bright and handsome, and very pleasing to the eye. The flavor is good, either as a table berry or for preserving. One of the best features about this berry is its long and continued season of bearing, la-ting as it does each year for a period of from twenty-five to thirty days, and the last of the fruit quite as large as the first.

Price per doz. $25 \mathrm{c}$, , per $10060 \mathrm{c}$, per I000 $\$ 3.00$.

Gandy (Perfect Flowers.)-Its lateness and fine flavor make it an acquisition to the home garden, also to the market gar-

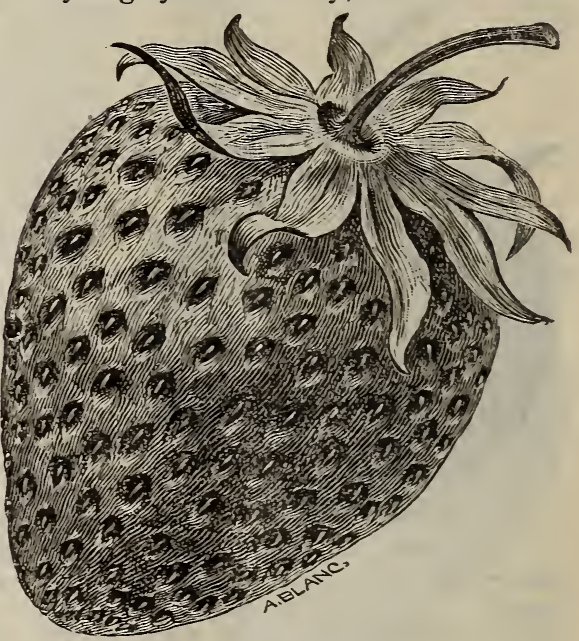

LOVE'T'T'S EARLY.

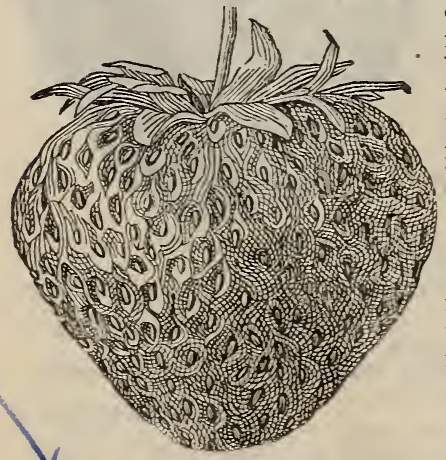

dener. The plant is a strong, compact grower; it is very productive, of large size; handsome, regular berries, which hold out large to the last picking. The fruit is bright, beautiful, one of the best, if not the best for market we have; but its superior flavor is what commends it to all in search of a good late berry in every respect. The Gandy is a perfect flowering variety.

Price per doz. 25c., per I00 6oc., per I000 $\$ 3.50$.

The Bubach.-Is a pistillate variety. The fruit is quite firm, of good flavor, dark, rich color and pleasing appearance. No one will make a mistake in planting largely of this splendid variety. Season second early. The Bubach has taken a very prominent place in strawberry culture.

Price per doz. 25c., per $10060 \mathrm{c}$., per $1000 \$ 3.00$.

Haverland (Pistillate variety). - It is exceedingly productive, long in shape, fruit ripening even all over, of very fair quality and a very good shipper. The plants are very fine, strong, healthy growers.

Price per doz. 25c., per I00 60c., per $1000 \$ 3.00$. 
Kirkwood (Perfect Flowers).-One of the leading market berries. Perfect flowering variety. Quite early to very late. Wonderfully productive, large to very large, splendid color, flavor of the very best, while for shipping qualities it ranks among the first.

Price per doz. 25c., per $10060 c$., per $1000 \$ 3.00$.

Sharpless (Perfect Flowers).-One of the most popular strawberries of the day. The plant is exceedingly large and vigorous, quite free from rust or blight. It demands well enriched soil and one that will bring the home grower fine fruit. It does not require especially heavy soil to succeed. A variety that is highly thought of by a great many growers, and quite extensively planted throughout the country.

Price per doz. $25 \mathrm{c}$., per $10060 \mathrm{c}$, per $1000 \$ 3.00$.

Warfield (Pistillate Variety).-It is really an improvement on the Crescent, which it looks like in the growth of plant, but is entirelv different from it in

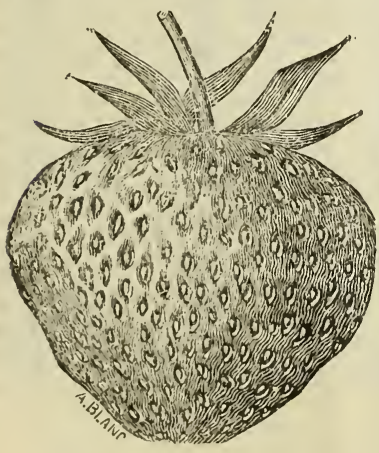

CHARLES DOWNING. the fruit, having a rather long neck, of richer color than Crescent, and of much better flavor. The fruit is small, firm and hapdsome. Very early.

\section{Charles Downing} (Perfect Flowers) - A very reliable, yood, old standard, perfect flowering variety. A leading market berry, and especially valuable for home use, of excellent flavor, a very desirable berry.

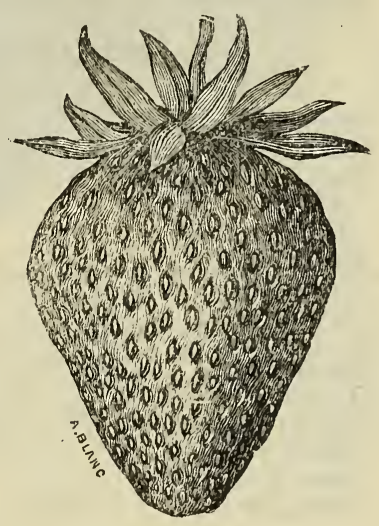

WA RFIELD. Price per doz. $25 \mathrm{c}$., per $10060 \mathrm{c}$, , per $1000 \$ 3.00$.

\section{ADDITIONAL VARIETIES.}

We have the following varieties in stock and ready for shipment at any time during the season :

Beder Wood, Jessie, Wilson, Banquet, Shuckless, Orange County, Dayton, Van Deman, Timbrell.

Price for any of the varieties named above : 25c. per doz., 6oc. per 100.

\section{POT GROWN STRAWBERRY PLANTS.}

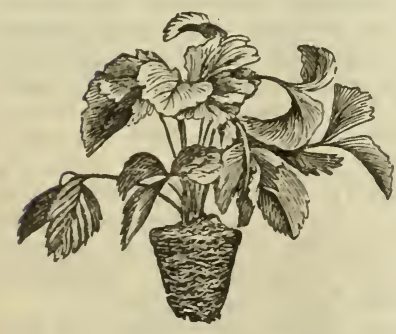

READY FOR SHIPMENT.

We have a fine large stock of all the following varieties grown in pots. Thest plants can be set in the early Spring and will yield a good crop of fruit the coming season. I wuuld recommend these plants to those who are about to plant a bed this Spring, and are anxious to procure the, large fruit the first season after planting.

Each plant with its mass of roots and with rich soil attached to them, is wrapped in paper and packed in moss. With this treatment the plant never suffers any drawback, and if planted properly, in reasonably good ground, will begin growing rapidly at once. One can readily understand how a plant of this kind set in 
soil about April I, thus having over two months to grow before fruiting, will produce a large quantity of handsome fruit.

For the last two seasons we have been unable to supply the demand for these pot grown plants. The call for them is increasing at a rapid rate each year. With this fact before us, and having from thirteen to fifteen acres of strawberries growing at our nurseries, we have grown for this Spring's trade over 25,000 of these pot grown plants (in addition to the ordinary layer plants that we gruw by the million.) We have made the price for them as low as possible for strictly first-class, large pot grown plants, and expect to dispose of all we have early in the season. Please note that the varieties we offer below are the best and most profitable sorts under cultivation. Send in your order for these p!ants as early as possible. Remember, we can ship pot grown plants most any day in the year.

VARIETIES AND PRICES OF POT GROWN PLANTS.

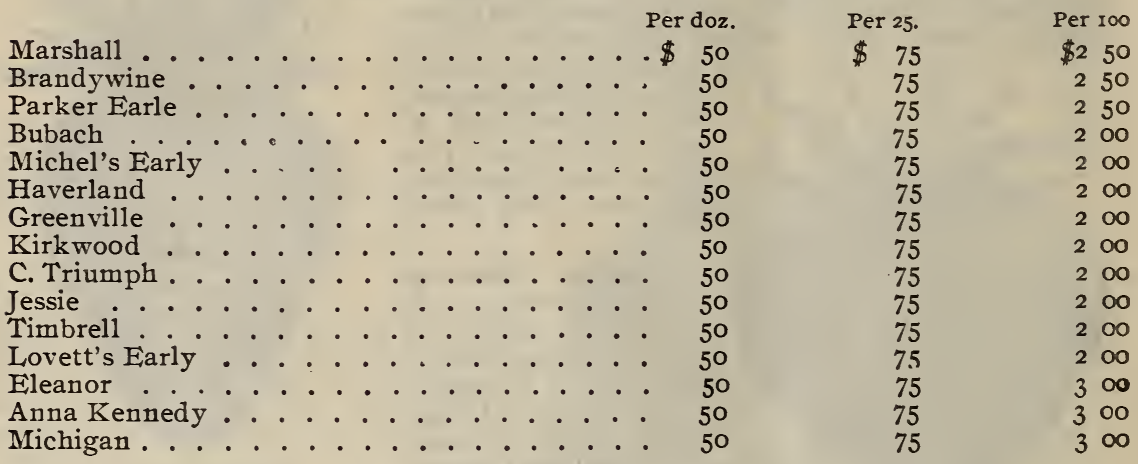

\section{STRAWBERRY-RASPBERRY.}

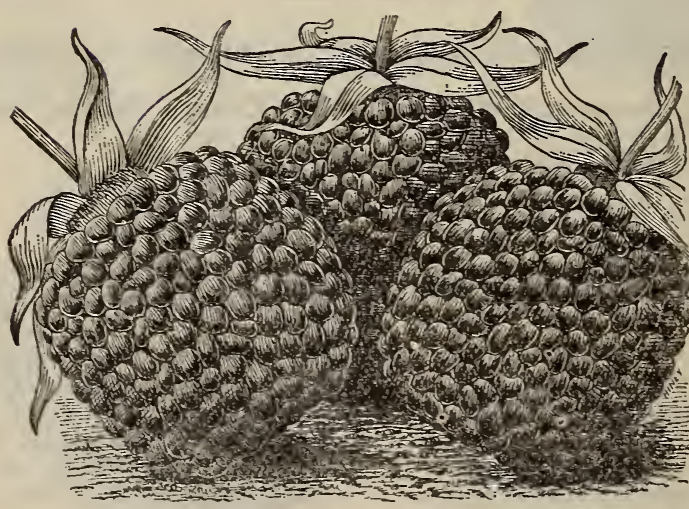

STRAWBERRY RASPBERRY.

It comes to us from Japan and is sald to be a hybrid between the Strawberry and Raspberry. That the plant is entirely hardy without protection and a prolific yielder, we can bear testimony from personal observation of plants in our trial grounds. In habit of growth the plant is distinct from both the fruits named. The root is perennal, throwing up numerous strong branching shoots, which produce large, beautiful berries from early in July until freezing weather. The berries are globular, slightly oblong in form, ranging in size from $1 / 1 / 4$ to $1 \frac{1}{2}$ inches long and one to $I 1 / 4$ inches in diameter. The blossoms resemble in appear. ance small single roses, snow white in color, and are as richly and deliciously fragrant as Gardenias. This description is frcm the introducer's catalogue.

Strong pot-grown plants, which can be shipped with entire safety, and will produce a full crop next Summer, each, 25c.; doz., $\$ 2.50$; Ioo, $\$ 15.00$. 
The Logan Berry (Introducers description in part). - This berry which is a true hybrid between the red raspberry and blackberry, was produced in California; it has proved entirely hardy at the East and North. The berries are of enormous size-fully equalling the largest blackberries, which they resemble in form and structure. In flavor they are rich and sprightly - a mingling of the raspberry and blackberry, mellowed and refined, but distinct from either-and they are melting and without core. In firmness they are like a blackberry and keep a long time either gathered or upon the bush after ripe, before spoiling. The flavor is so lucious, novel and rich, the berry cannot fail to please everybody as

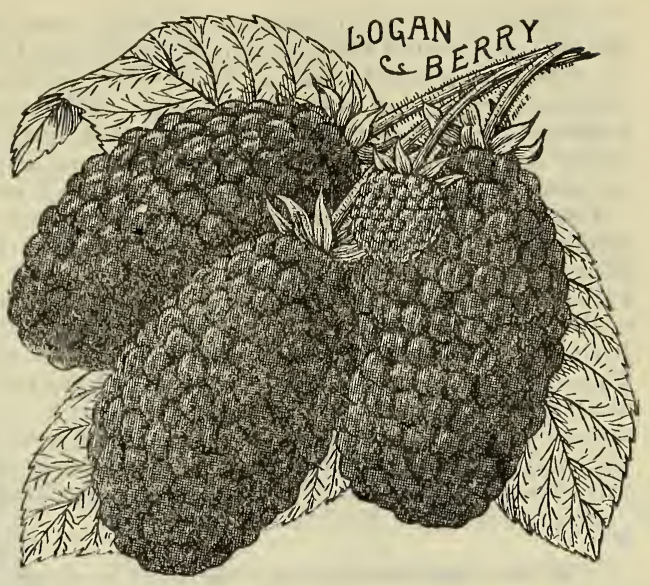
a dessert fruit. For canning it is superior to all the other small fruits, and for jellies and jams it is said to be unequalled also.

The canes, which are exceedingly prolific, are of strong vigorous growth. What gives special value to this norel fruit is its earliness, ripening as it does at the close of the strawberry season, and in advance of all but the very earliest raspberries. The past season we gathered ripe berries off it on June 20 th, in I895 on June 24 th ; it continuing each year to give us ripe berries for three weeks, perfecting all its fruit, even the last, to full size, firmness. color and flavor.

Good tip plants, each 25 c., 3 for 60 ., doz. $\$ 2.00$; $100 \$ 15.00$.

\section{RED RASPBERRIES.}

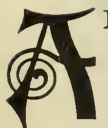

FTER preparing the ground the same as you would for strawberries, set the plants six feet apart between the rows, and one foot apart in the row, thus making a continuous row for fruiting, which gives one-third more fruit than by the hill system. Set posts 20 feet apart, and run one wire $31 / 2$ feet from the ground, and train your fruiting cane to the wire-this is the cheapest and best method, and is being adopted now quite generally. My stock of raspberries is very fine and large.

To plant an acre of raspherries, as advised above, namely, six feet apart between the rows, and one foot apart in the row, would require 7,260 plants-the number of times six will divide into 43,650 , which is the amount of square feet contained in one acre of land. Some advise planting a greater distance apart in the rows, but we have legrned, from many years of practical experience, and from our observation of the pla)tations of our neighbors, who have hundrerls of acres of raspberries in fruiting within/a radius of a few miles around us, that the distance we advise above is the best, and vill give most satisfactory and profitable results.

THE LOUDON RASPBERRY.-(See cut on back cover of catalogue.) way :

Mr. E. S. Carman describes the Loudon in the "Rural New Yorker," in this

Loudon is the finest hardy red we know of. Some of the berries are nearly round, some are decidedly conical, more so than those of Cuthbert. When ready to pick, the color is a bright red, the berry firm. When dead ripe, the color is a darker red, but not at all purple.

August I. -Now that Cuthberts are gone, Loudon is still bearing. 
We wish to add to the above valuable and trustworthy evidence our own experience. We fruited the Loudon at the Orange County Nurseries the past season, and we were well pleased with it. The fruit is very large, exceptionally firm, of fine, rich, attractive color, and of the best flavor. The canes are fully as larye and strong as the Cuthbert. The Loudon may develop bad qualities as it grows older; but, as far as the writer can learn, and from his own observation, it will become, ere long, a popular market raspberry, something we are much in need of at the present time.

The above was written fur our Irg6 calalogue. After another years fruiting of the Loudon we are even more favorably impressed than ever with its worth. As grown here at our nurseries the canes are very strong and vigorous, probably larger than either Cuthbert or Marlboro which were without doubt the rankest growers we had in the Red Raspberry. Thus far the Loudon has proved entirely hardy here with us. It ripens three to four days after the Marlboro and continues in fruiting a long time. The plants are so vigorous that the last of the fruit is quite as large as the first. This, as all well informed fruit growers know, is a very desirable feature for any fruit to possess and particularly so with a good market raspberry. The fruit is very firm and will make a good shipping berry. We have great faith in the future of this berry for this reason we have made a large planting of it the past fall.

Plants each I5c., doz. $\$ 1.00$, 100 $\$ 6.00$.

Miller Red Raspberry. - Berry is as large as Cuthbert, holding its size to the end of the season ; round in shape, color, bright red; core very small; does not crumble, making it the firmest and best shipping berry in existence; has a rich, fruity flavor. The time of ripening is the very earliest. This new berry has given such good results in many places that many large fruit growers have discarded all other varieties and are now growing it exclusively. The Miller Red will be a good mate for the Loudon as it ripens several days in advance of Loudon. With us it is a very fine grower. We will fruit it quite largely the coming season.

Price doz., 50c.; 100, $\$ 1.00 ;$ 1,000, $\$ 8.00$.

\section{YOU CAN SAVE TEN PER CENT.}

We will allow you a discount of ten per cent. on any order to the amonut of $\$ \mathrm{I} .00$ and upward, provided, the same reaches us before March I5th. (We cannot allow this discount on the family lists named in this catalogue.)

Marlboro. - The canes of Marlboro are strong. hardy and productive; the fruit is as large as the Cuthbert, crimson in color, holds out large to the last picking and arrives in market in good condition. We have a fine, la ge stock of these plants and would like a chance to figure on any large quantity needed. Per dozen, 30 cents; per I00, $\$ 1.00$; per I,000, $\$ 7.00$.

Cuthbert. - The best late hardy red raspberry, a variety that adapts itself to all conditions of soils and climates, succeeding admirably North. South, East and West. The canes make a very strong, vigorous growth, and are exceedingly productive of fine, large, late good flavored fruit, which holds its size to the end of the season. The berries are dark crimson in color and quite firm. Per dozen, 30 cents; per I00, $\$ 1.00$; per I, 000, $\$ 7.00$.

Thompson's Early Prolific.-This new raspberry combines extreme earliness, hardiness, vigorous growth and productiveness with beautiful color, firmness and fine quality to a remarkable degree. It commences to ripen toward the close of the strawberry season and giv s g rod picking from the first. Those who desire an early red raspberry can safely give this a trial. Price per doz., зoc.; I00, $\$$ I.c0; 1, 0 . o, $\$ 8.00$.

Othor Red Varieties we have for sale are Brandywine, Turner, Hudson River Antwerp, Royal Church. 


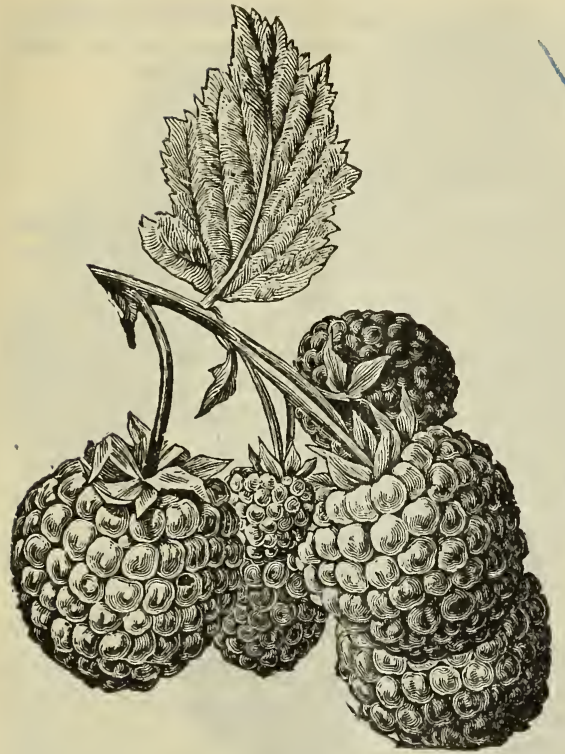

GOLDEN QUEEN.

Prices for any of the above varieties per dozen. 30 cents; per Joo, $\$ 1.00$; per $\mathrm{I}, 000, \$ 7.00$.

Golden Queen.-The Queen is larger than Brinckle's, firmer, of a much better culor; the canes are laryer, more productive, and the best of all they are hardy, the lack of hardiness having made Brinckle's Orange an unpopular fruit. No first-class home fruit garden is complete without a good bed of it. It is without doubt one of the finest flavored fruits I have ever tasted, and this voices the opinion of many who tasted the berry on my place.

Price per dozen, 30 cents; per 100, $\$ 1.00 ;$ per 1,000, $\$ 7.00$.

Caroline.-The leading pink variety and one that is being planted very largely for market. The canes are strong growers, and when in fruit are one mass of beautiful pink herries, large in size, of a sub-acid, but pleasant flavor.

Per dozen, 3oc.; per 100, $\$ 1.00$.

\section{CAP RASPBERRIES.}

In the planting and cultivation the same rules govern as for the red raspberries.
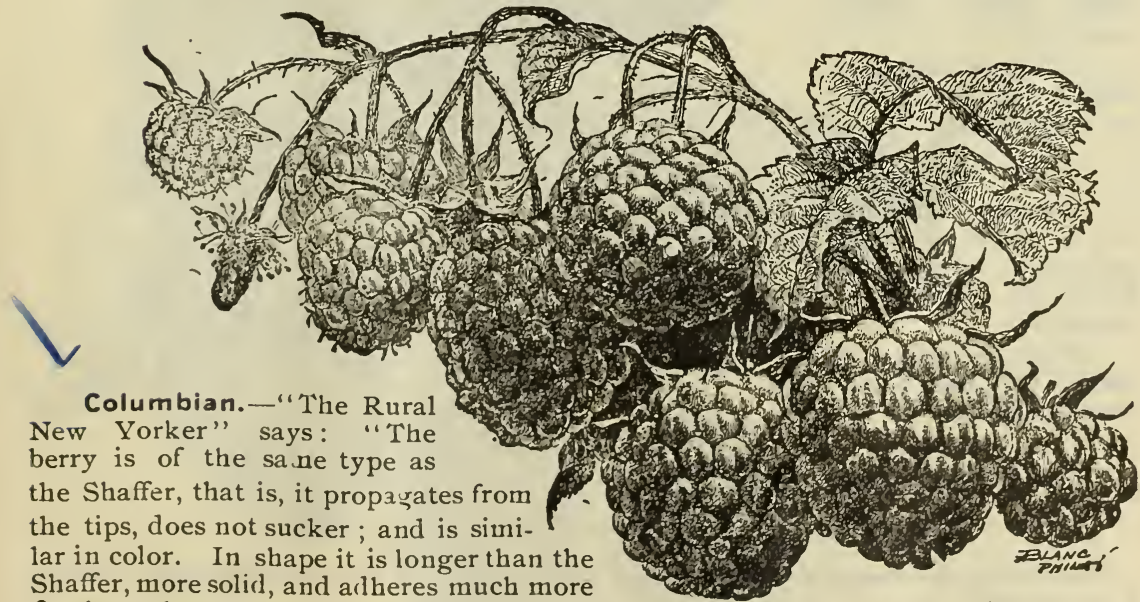

New Yorker" says: "The berry is of the sane type as the Shaffer, that is, it propayates from the tips, does not sucker; and is similar in color. In shape it is longer than the Shaffer, more solid, and adlheres much more firmly to the stems In quality it is an improvement on the Shaffer, being sweeter when ripe and of higher flavor. These comparisons are made with the Shaffer because we can thus best illustrate, and because of the fact that the Shaffer is to day probably the most productive raspberry under cultivation. In general appearance both are 
much alike in foliage and cane. On close examination marked differences are seen. The canes of the Columbian are much more woody, its thorns are a bright, light green in color, while those of the Shaffer have more or less of a purple tinge.

Price each I5c., doz. $\$ 1.25 ; 100 \$ 6.00 ; 1000 \$ 50.00$.

\section{YOU CAN SAVE TEN PER CENT.}

We will allow you a discount of ten per cent. on any order to the amount of $\$ 1.00$ and upward, providing the same reaches us before March 15th. (We cannot allow this discount on the Family Lists.)

Shaffer's Colossal. (Pinkcap.)-The largest of all the cap rasperries. The canes are strong, hardy and productive of large, handsome fruit, the last of the berries being even larger than the first. It is a valuable addition to the cap family end especially valuable for preserving. Price doz. 50c., 100 $\$ 1.25 ; 1000 \$ 10.00$.

Ohio.-Ripens mid-season, between Souhegan and Gregg. The fruit is nearly as large as the Gregg. Very uniform in size and holds out large to the last picking. The color is nearly as black as the Souhegan. It is of splendid quality, firm and a very excellent shipper. Canes are vigorous and hardy, and can always be relied upon for a fine crop of fruit.

Price per dozen, 30 cents; per 100, $\$ 1.00$; per $1000 \$ 7.50$.

Palmer.-Early and very productive berries; large canes, strong growers.

Price per dozen, 50 cents; per 100, $\$ 1.00$; per 1000, $\$ 8.00$.

Kansas - Mid-season in ripening; fruit large, firm, of splendid flavor and pleasing appearance.

Price per dozen, 50 cents; per 100, $\$ 1.50$; per $1000 \$ 10.00$.

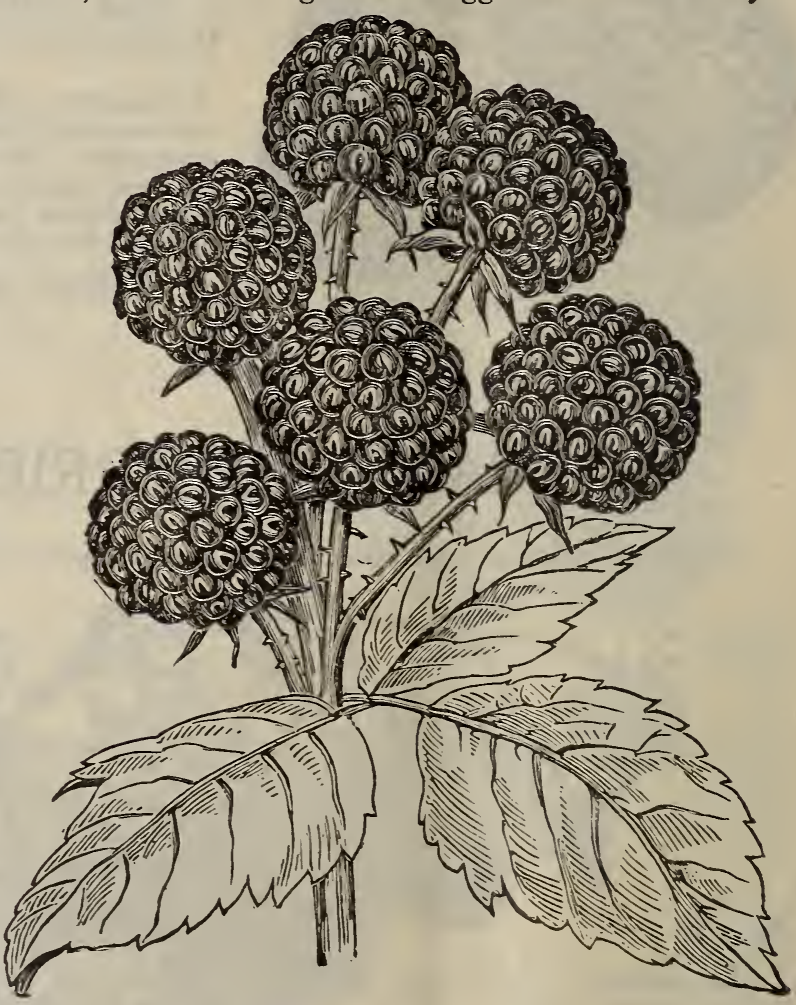

OHIO.

\section{REPORT FROM LAST ORDER OF THE SEASON.}

The very day we are going to press for our 1897 Catalogue we received the following from one of our patrons :

Mr. T. J: DWYER,

McKeesport, Penna., Dec. II, I896.

Dear Sir-The Trees and Goosberries arrived in good condition and I am well pleased with the Stock. I remain, 
Lovett Raspberry.- "The canes are of vigorous growth, the tallest being over

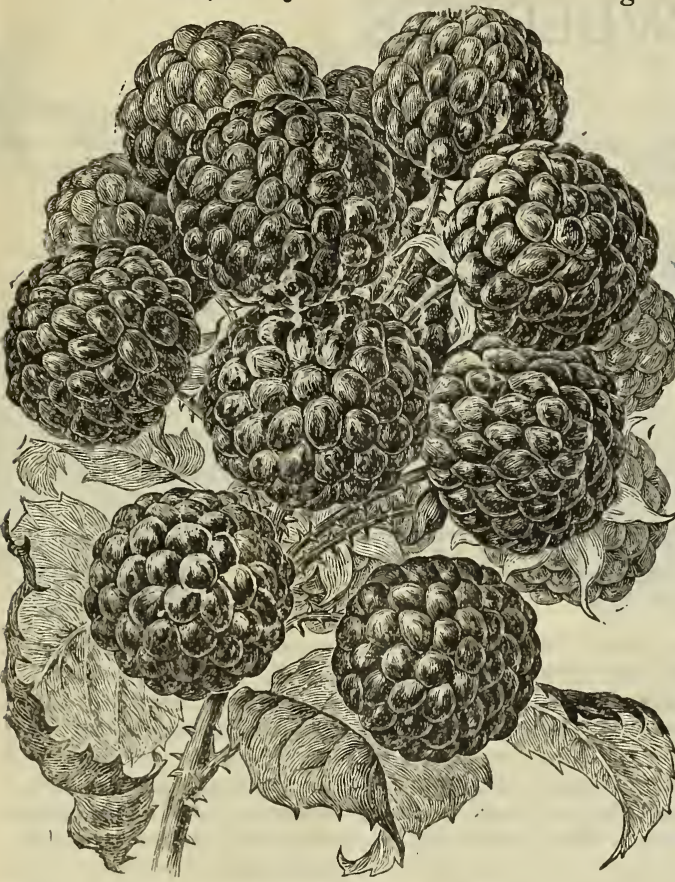

THE LOVETT. six feet. The berries are borne in short racemes somewhat like those of Gregg ; are nearly as large; black, glossy, with some bloom around the base of the drupelets. They are as firm as it is desirable a blackcap should be, and never drops from the receptacle.

Price per dozen. 50 cents; per I00, $\$ 1.50$; per 1000, $\$ 10.00$.

Souhegan.-Canes very vigorous, branching quite freely; with many strong, sharp pines; enormously prolific of jet black berries, and the best in quality of any blackcap; the very earliest to ripen, coming with the later varietics of strawberries. It is by odds the most valuable blackcap, either for family use or market of any of the older sorts.

Price per dozen, 30 cents ; per I00, $\$ 1.00$; per 1000, $\$ 7.50$.

Gregg. - Requires a good, itrong soil to produce best results, and responds liberally to generous treatment.

Price per dozen, 30 cents; per IOO, $\$ 1.00$; per I,000, $\$ 7.50$.

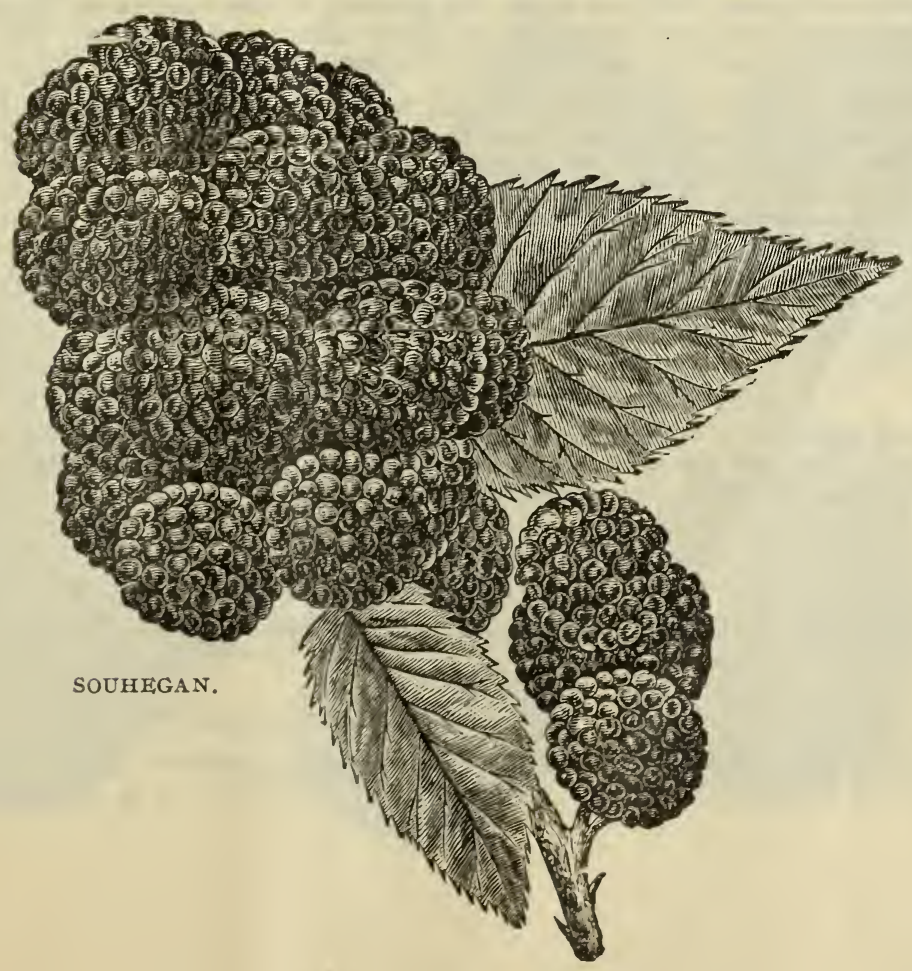




\section{DEWBERRIES.}

$1 \mathrm{HE}$ best manner of cultivating is to set the plants in rows three feet apart and eight feet apart between the rows, allowing them to make a matted row about four feet wide, and to mulch the ground as soon as the blossoms appear, thus keeping the fruit from getting muddy with the rain.

Lucretia.- Is the best varieiy and the one we grow. We have been much interested and delighted with this fruit, which ripens a few days in advance of the blackberry, and is productive of large, fine-flavored, luscious fruit without any core. When people realize the value of this fruit it will be a welcome guest to their garden.

Price per dozen, 50 cents; per 100, $\$ 1.50$; per 1000, $\$ 10.00$.

\section{BLACKBERRIES.}

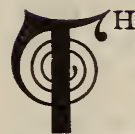

$\mathrm{HE}$ ground should be prepared the same as for raspberries. Set the plants eight feet apart between the rows, and eighteen inches apart in the row, thus making a continuous row for fruiting. which gives one-third more fruit than by the hill system. Set posts in the row twenty feet apart, and run two wires on these posts. Run one wire three feet from the ground, and the other wire five feet from the ground,and trail and tie your fruiting canes to these wires. This is the cheapest and best method, and is being adopted now quite extensively in place of the old hill system. The blackberry succeeds well in most any soil, and the land would be poor indeed that could not give a good crop of this fruit. The blackberry is one of the most profitable of fruits, and the demand for it is increasing very rapidly each year. We have made the growing of these plants one of our specialties, and have a very fine, large stock of all the plants named below. We would ask for a chance to figure on any large order for plants.

Eldorado. - It has been in cultivation twelve years, and under careful test at different experiment stations for four years. In every case they report it high above any other variety, and all agree that it has never winter killed or failed to produce a full crop of the finest fruit. While it is of superior flavor and very large, the vines will also stand the winters of the far northwest without injury. The fruit has no hard core, but when placed in the mouth melts away, being most pleasing to the taste and very sweet. The yield is enormous, the fruit being jet black, in large clusters, ripening well together. Its keeping quality is unsurpassed.

Price each I5c., per doz. $\$ 1.00,100 \$ 5.00$.

\section{YOU CAN SAVE TEN PER CENT.}

We will allow you a discount of ten per cent. on any order to the amount of $\$ 1 . \infty$ and upwards, provided the same reaches us before March I5th. (We cannot allow this discount on the family lists named in this catalogue.)

OlNeyville, R. I., Apr. 27, 1896.

MR. T. J. DWYER,

Dear Sir-The peach trees and other things arrived in good condition; have set them out. Yours truly,

ROBERT BOWEN.

South Deerfield, Mass., March 7, 1896.

T. J. DWYER,

Dear Sir-Quince bushes received all right to-day, also have received in good condition the Currant bushes. Yours truly,

C. D. EVERETTE. 
Erie.-This superb new fruit originated in northern Ohio, not far from the shore of Lake Erie. It is the best hardy variety yet introduced, very productive, not having failed in producing a fine crop each year since it was originated; foliage clean and healthy, free from rust; fruit large, about the size of Lawton; ripens early.

Price per dozen, 50 cents ; per I00, $\$ 2.00$; per I,000, $\$ 20.00$.

Kittatinny. - Long the most popular of all blackberries for general planting, and still unexcelled for main crop in the home garden or for market in some locations. Berries large, handsome and of delicious flavor; canes of strong, erect growth and productive. Medium to late.

Price per dozen, 40 cents; per I00, $\$ 1.00$; per I,000, $\$$ I0.00.

Snyder. - This as an early variety and the Taylor's Prolific as a late sort are the two recognized sorts of blackberries, both being hardy and productive. The fruit of the Snyder is small in size, but of a sweet, juicy, excellent flavor, without the hard core of many other sorts.

Per dozen, 35 cents; per 100, \$1.00; per r,000, \$9.00.

Taylor's Prolific.-An old, reliable and trustworthy variety. A suitable companion for Snyder, for it also is a variety of great hardiness and productiveness, but ripens somewhat later. Berries are very much larger and of fine flavor. Canes of strong growth and iron-clad hardiness. Season late.

Per dozen, 40 cents; per 100, $\$ 1.00$; per I,000, $\$ 10.00$.

Agawam.-Excellent for the home garden and desirable, as an abundant supply of good berries may be raised with but little trouble. Unlike most blackberries, fully ripe as soon as black. Mid-season.

Per dozen, 40 cents; per 100, $\$ 1.00$; per I.000, $\$ 10.00$.

Stone's Hardy.-As prolific as Snyder; a little larger in size, and of superior quality. Ripens late.

Per dozen, 40 cents; per 100, $\$ 1.00$; per I,000, $\$ 10.00$.

Lawton (New Rochelle.)-An old favorite, esteemed for its productiveness and large size. Delicious when fully ripe. Season medium.

Per dozen, 50 cents; per 100. \$1.00.

Early Harvest - This is one of the earliest blackberries yet produced ; ripening two weeks before Wilson's Early. Of good quality. It is hardy. While a good berry in other respects, its distinctive value is its earliness.

Price per dozen, 50 cents ; per 100, $\$ 1.00$; per I,000, $\$ 7.00$.

Wilson Early._An early variety of large size and very popular in the south; needs protection in the north.

Per dozen, 50 cents ; per I00, $\$ 1.00$; per I,000, $\$ 7.00$.

Wilson Junior. - Said to be an improvement on the Wilson Early, which is its parent.

Per dozen, 50 cents; per I00, $\$ 1.00$ : per I, 000, $\$ 7.00$.

\section{CURRANTS.}

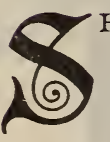

HOULD be planted in a good, rich, moist spot. No fruit responds more liberally to manure and thorough cultivation, and none will depreciate more in size, quantity and quality from neglect than the currant. One great mistake made is planting too close to each other. For garden culture they should be set five feet apart each way, and for field culture they should be planted six feet apart each way. Thorough. clean cultivation between the rows and around the plants is essential to the hest results. Should the currant worm appear, use one teaspoonful of hellebore to two gallons of water, and with water can or hose sprav the leaves with this solution. A syringe can also be used for this purpose. Prune thoroughly each year by cutting out all the old wood and heading off the new growth one-half each year. The currant is one of our most profitable fruits, and when 
properly planted, so as to admit of cultivation botll ways, the cost of labor is very slight. We grow currants in very large quantities; and in addition to the large and fine stock we have to offer for sale this Spring, we have now in the ground for the Fall trade of I897 and the Spring trade of İ98, over one hundred thousand plants and cuttings.

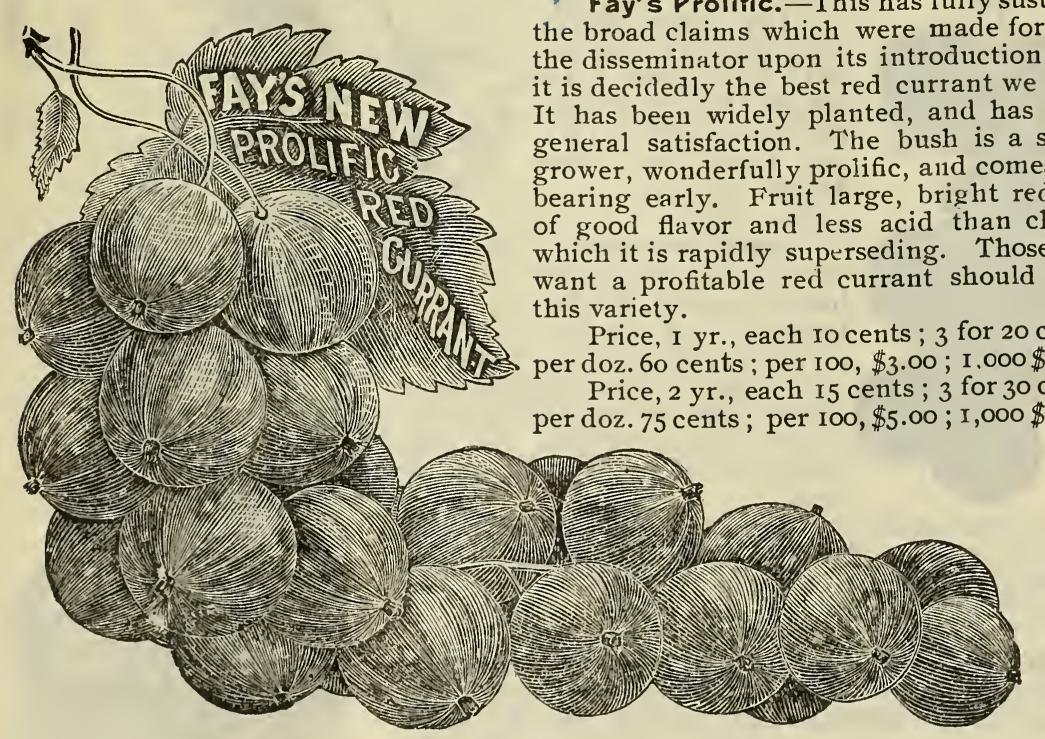

YOU CAN SAVE TEN PER CENT.

We will allow you a discount of ten per cent. on any order to the amount of $\$ I$ and upward, providing the same reaches us before March 15 th. (We cannot allow this discount on the family lists named in this catalogue.)

North Star. - A large, handsome, new red variety, very productive of large fruit. The fruit is sweet, sprightly, and rich in flavor, and a good firm market fruit.

Plants one year, each I5 cents, per dozen $\$ 1.00$; plants two years, each 20 cents, per dozen, $\$ 1.50$.

Cherry. - This is the old established standard variety of red currant. Very prolific of fine, large bunches of most beautiful crimson berries. A splendid variety for home use, and excellent as a market fruit.

Price, one year, per dozen, 50 cents; per Ioo, $\$ 3.00$; per I,000, $\$ 25.00$. Two years, per dozen, 60 cents ; per I0o, $\$ 3.50$; per I, 000, $\$ 30.00$.

Versailles. - This is so near like Cherry that the one description will answer for both. Price for Versailles is the same as for the Cherry.

Victoria - This is the latest variety we have in currants, ripening ten to twelve days later than the Cherry. Especially desirable for the home use, and also valuable as a market berry.

Price, one year plants, per dozen, 60 cents; per Ioo, $\$ 3.00$. Price, two year plants, per dozen, 60 cents; per I0o, $\$ 3.50$.

Red Dutch. - A popular old variety, very productive. The fruit is small as compared with the ahove varieties When fully ripe it is very sweet; this, with its tendency to remain on the bushes in good condition for a long time after it becomes fully ripe, makes it a very desirable fruit for family use.

Price, one year, per dozen, 50 cents; per Ico, $\$ 3.00$; per I,000, $\$ 25.00$. Price, two years, per dozen, 60 cents; per I00, $\$ 3.50$; per I, 000, $\$ 30.00$. 


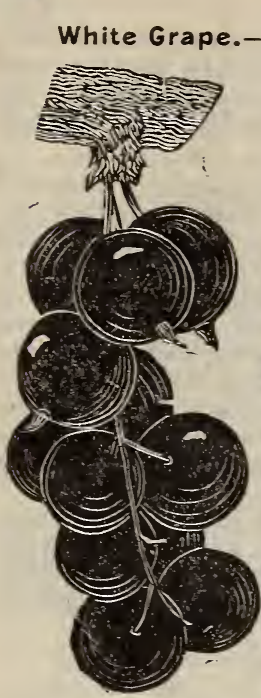

LEE'S PROLIFIC.

-Very large, yellowish white; sweet or very mild acid; excellent quality and valuable for the table; the finest of the white sorts. Very productive, and a most desirable currant.

Two year plants, per dozen, 6o cents ; per I00, $\$ 300$; per 1,000 $\$ 25$ oo. One year plants, per dozen, 50 cents ; per IOO, $\$ 2.50$; per 1,000 $\$ 22.50$. $\mathrm{V}$

Lee's Prolific. The best European black currant yet introduced, and one that makes a great advance in the fruit of $i$ is class. It is earlier than Black Naple, and of superior quality; larger, longer clusters, and even more productive than that prolific kind.

Two year plants, per dozen, 60 cents; per Ioo, $\$ 3.50$; per $1.000, \$ 2500$. One year plants, per dozen, 50 cents ; per I0O, $\$ 2.50$; per I,000, $\$ 20.00$.

Black Champion.- This new variety comes from Fngland, and has been pronounced by a committee of the Royal Horticultural Society as the finest black currant ever exhibited. The bunches are very large, and the flavor of the fruit particularly delicious.

Plants, one year, per dozen, 75 cents. Two year plants, per dozen, $\$ 1.00$.

$\checkmark$

The Dwarf Juneberry is of easy culture, and is a good substitute for the Swamp Huckleberry, which it resembles in appearance and quality. The fruit is borne in clu-ters, reddish purple in color, changing to bluish black. In flavor it is of a mild, rich sub-acid, excellent as a dessert fruit or canned. It is extremely hardy. Should have a place in every garden. Plants each, ro cents; per doz., $\$$ r.00; per 100, $\$ 5.00$.
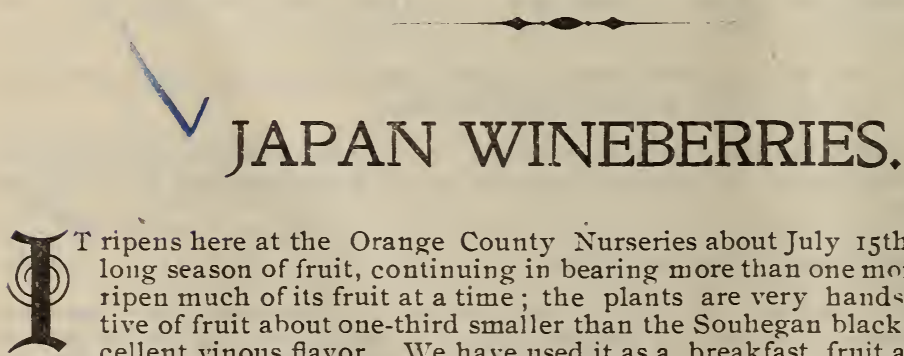

ripens here at the Orange County Nurseries about July I5th, and has a very long season of fruit, continuing in bearing more than one month. It does not ripen much of its fruit at a time; the plants are very hand ccme and productive of fruit ahout one-third smaller than the Souhegan black cap. It is of excellent vinous flavor. We have used it as a breakfast fruit and found it very enjoyable. The Japan IVineberry has proved hardy with us, and we would advise at least 50 plants in every garden.

Plants each, Io cents; per dozen, 75 cents; per Ioo, $\$ 3.00$. 


\section{GOOSEBERRIES.}

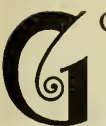

OOSEBERRIES require the same treatment in planting, pruning and cultivation as recommended for the currant. With a little care in keeping off the currant worm, and fair cultivation, enormous crops can be grown, and profitable results can be had in growing gooseberries. Owing to the improved varieties and to good results obtainted from spraying for the last three years, the gooseberry has beccme very profitable, hence very popular, and is being planted very extensively.

Red Jacket. - It is a new gooseberry, and the best red one in existence, with good foliage, mildew proof, productive, fruit of excellent quality. This berry seemis to be of especial value on account of its claim to be mildew proof-which will be an acquisition to people residing in localities where other varieties mildew badly.

Plants, one year, each, 30 cents; per dozen, $\$ 2.00$. Plants, two ytars, each 35 certs; per dozen, $\$ 3.00$.

Golden Prolific.-Fruit is large, of a deep golden yellow, of excellent quality, and very attractive in appearance. A heavy fruiter, and, I believe, is destined to become as popular as the Industry.

Price. one year, each, 25 cents; per dozen, $\$ 1.50$. Plants, two years, each, 30 cents ; per dozen, $\$ 2.00$.

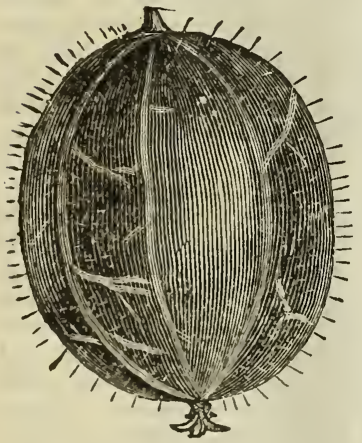

INDUSTRY.

Industry. - The best English gooseberry yet introduced; of vigorous, upright growth; greatest cropper and freest from mildew of any of the English varieties ; berries of the largest size, one and one-half inches in diameter, and one of the most excellent flavor, both pleasant and rich; color, when fully ripe, dark red.

Price, one year, each, ro ctnts; per dozen, $\$ 1.00$; per I0o, $\$ 7.00$. Price, two years, each, I5 cents; per dozen, $\$ 1.25$; per 100, $\$ 8.00$.

Downing.-Very popular, 1arge, pale-green, good quality; bush vigor us, hardy and prolific. One of the best varieties ever introduced. This noble variety, named after the lamented Charles Downing, has not been surpassed for general purposes. It is free from mildew, being a native seedling. It forms a handsonie, large and productive bush, and the fruit hangs in thick and close rows beneath.

Price, one year plants, per dozen, 60 cents; per ıoo, $\$ 4.00$. Price, two year plants, per dozen, 75 cents ; per $100, \$ 5.00$.

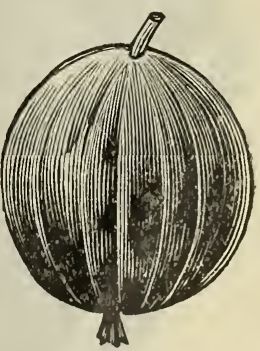

DOWNING.

Houghton.-A medium-sized American variety; fruit smooth, red, tender and very good ; bears abundant and regular crops. Free from mildew and sure to bear a crop even under neglect.

One year plants, per dozen, 60 cents; per Ion, $\$ 3.50$. Two year plants, per dozen, 75 cents ; per 10o, $\$ 4.50$.

Chautauqua.-A valuable berry, probably of foreign origin, but showing lessten ${ }^{-}$ dency to mildew than any of its class. A vigorous, upright grower, and wonderfully prolific. Berries large, pale yellow, smooth, very sweet and of exquisite flavor.

One year, each, 50 cents; per dozen, $\$ 4.00$. Two years, each, 75 cents; per dozen, $\$ 6.00$.

\section{YOU CAN SAVE TEN PER CENT.}

We will allow you a discount of ten per cent. on any order to the amount of $\$ 1.00$ and upward, provided the same reaches us before March 15 th. (We cannot allow this discount on the family lists named in this catalogue). 


\section{HARDY GRAPES.}

\section{GENERAL INSTRUCTIONS.}

The best soils are those containing more or less clay, with a mixture of disintegrated rock, rotten shale, small stones, limestone, etc. Gravelly and sandy soils are often admirably adapted to the grape, as is also a sandy loam or alluvial soil when well drained. In short, the grape may be successfully grown in any dry soil of sufficient fertility to produce a good farm crop, if climate and exposure are favorable.

The only necessary preparation of the soil is thoroughly to plow and pulverize it to a depth of 12 to 18 inches. If naturally poor, it should be enriched by a liberal application of thoroughly rotted stable manure, when it can be had, bone dust, ashes, or other available fertilizers. Of the commercial fertilizers, those containing a large percentage of potash and available phosphates are most desirable.

When ready to plant, stake out the ground in rows, eight or nine feet apart, and six to ten feet in the row. Dig the holes about two feet wide and fifteen inches deep, loosening the earth thoroughly in the bottom, throwing in two or three inches of surface soil. Before the vines are taken to the field the tops should be cut back, so that when planted only two or three buds will be above ground, and the roots shortened to ten or twelve inches.

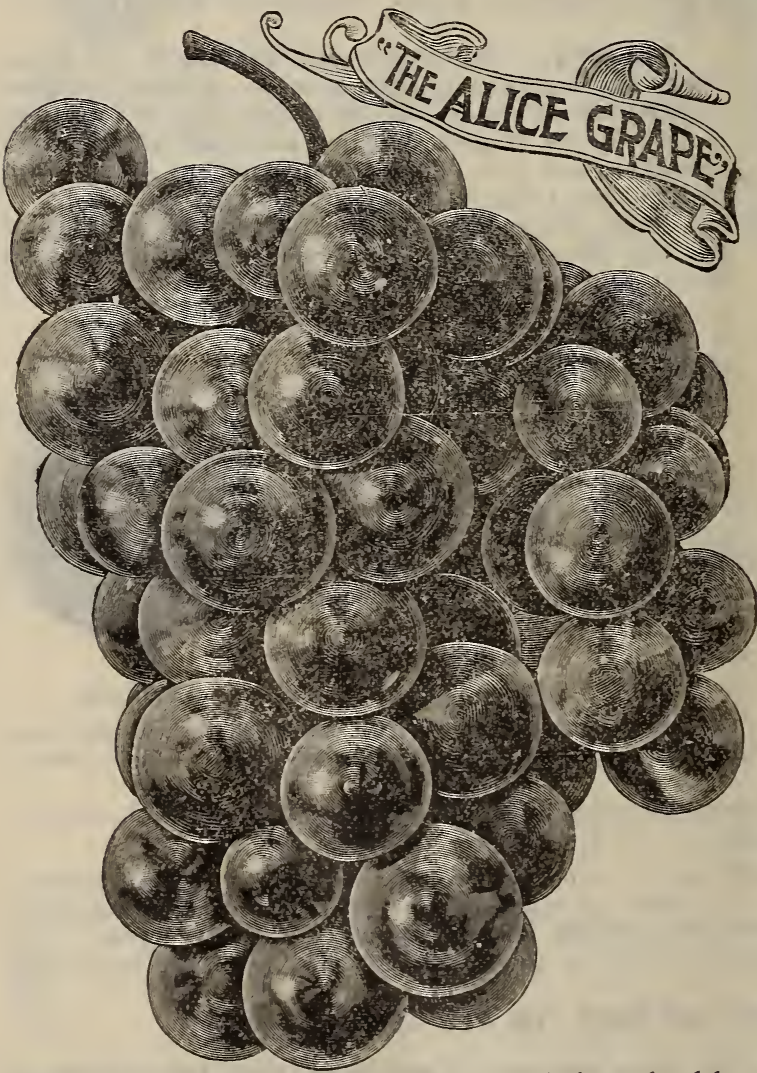

The Alice Grape.-The Alice grape is a native seedling of unknown parentage, found on a farm in Ulster County, N.Y. After Io years testing by the side or along with 20 other varieties, it is now offered as the coming grape. Iti s especially valuable for its long keeping qualities; this has been fully proved; kept in an ordinary cellar, without cold storage or special care, they will at the end of Winter. in February and March, be sound, plump and sweet. The value of a grape of high quality that can be held and marketed at any time during Winter will be conceded by every grape grower. The fruit is a pale red grape, darker when grown in shade, with abundant lilac bloom ; about the size of Catawba ; of fine flavor, high quality, free from foxiness, rich in saccharine; pulp meaty and tender, with few seeds and small; sweet to the center; skin thick and tnugh, without astringency. The vine is exceptionally vigorous and strong. many branches making 20 feet or more growth in a season.

Wood very haid, rip. 1s uniformly. Foliage healthy, large, thick, heavy, dark green, free from mildew; prolific-from 40 to 60 clusters on a well developed vine very hardy. (IVe believe it will prove to be one of the hardiest varieties grown.) A rerage weight 6 to 12 ounces, medium size, compact, mostly slightly shouldered, 
some not; ripens with Concord; berries cling to the stem firmly; is an excellent shipping grape ; does not rot; in time changes slowly to raisins.

Price 2 year vines, 75 cents each; $\$ 8.00$ per dozen.

Price

" 60 " each; $\$ 6.00$

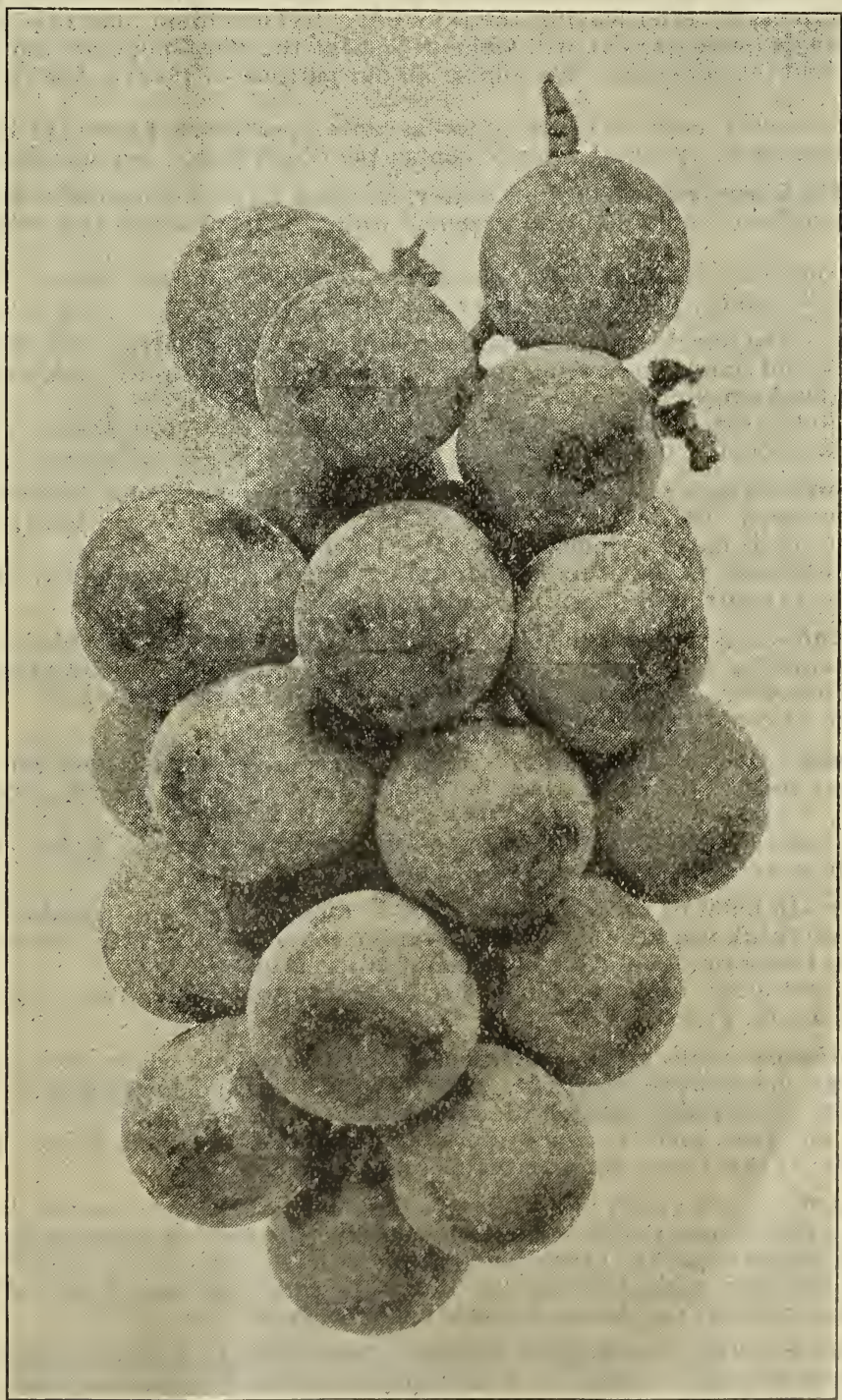

Early Ohio.-An extra early black grape, and very valuable on this account. It ripens one week in advance of Moore's Early, which make it the most profitable early black grape we have; the vine is hardy, productive, and the fruit of the best quality; the bunches are large, compact and handsome; berries medium, and of a sprightly pleasant flavor.

Price, one year, each, 35 cents ; 3 for $\$ 1$ oo ; per dozen, $\$ 3.00$; per roo, $\$ 18.00$. price, two years, each, 60 cents; 3 for $\$ 1.50$; per dozen, $\$ 4.00$; per 100, $\$ 25.00$. 
The Green Mountain Grape.-It stands at the head of the list for earliness, good bearing and vigorous, healthy growth. The berries of medium size; color, greenish white; skin, thin, and leaving no unpleasantness whatever in the mouth when eaten; pulp, tender and sweet, with a slight inclination towards the vinous. The seeds, which are only one or two to a grape, separate from the tender pulp with the slighest pressure after learing the skin. We feel confident that this grape possesses desirable qualities that will make it one of the most popular and profitable fruits of recent introduction. We advise all our patrons to plant a few vines of this grape.

Price, one year, each, 25 cents ; 3 for 60 cents ; per dozen, $\$ 2.00$; per $100, \$ 12.00$, Price, 2 years, each, 35 cents ; 3 for 90 cents ; per dozen $\$ 3.00$; per Ioo, $\$ 15.00$.

Moore's Diamond.-A prolific bearer, bunches large, handsome and compact, slightly shouldered; color delicate greenish white. Ripens about two weeks before Concord.

Price, one year, each, I5 cents; per dozen, 75 cents; per Ioo, $\$ 4.00$. Price, two years, each, 20 cents ; per dozen, $\$ 1.00 ;$ per roo, $\$ 5.00$.

Eaton.-The bunches are very large, compact and shouldered. The fruit is very large, black and handsome in appearance. The flavor is sprightly, juicy and sweet, and to our taste excellent.

Price, one year, each, 25 cents; per dozen, $\$ 1.50$; per Ioo, $\$ 8.00$. Price, two years, each, 30 cents; per dozen, $\$ 200$; per 100, $\$ 10.00$.

Agawam-(Roger's Hybrid, No. I5.) Red or amber color; bunch usually loose. shouldered; berries large, skin thick, flesh pulpy, meaty, juicy, of a rich, peculiar, aromatic flavor; ripens about with Concord.

Price, one year, each, Io cents ; per dozen, 50 cents; per I00, $\$ 3.00$. Price, two xears, each, I5 cents; per dozen, 75 cents ; per 100, $\$ 4.00$.

Brighton-Red; bunch medium to large, long, compact, shouldered; berries medium, skin thin, flesh tender, sweet, with scarcely any pulp; quality best.

Price, one year, each, Io cents; per dozen, 50 cents; per 100, $\$ 3.00$. Price, two years, each, I5 cents; per dozen, 75 cents ; per IOO, $\$ 4.00$.

Catawba-Dark red when fully ripe. Bunch large; berries medium to large, rich, vinous flavor, of best quality, both for table and wine; vine a good grower, hardy.

Price, one year, each, Io cents ; per dozen, 50 cents ; per $100, \$ 3.00$. Price, two years. each, I5 cents; per dozen, $\$ 1.00$; per 100, $\$ 4.00$.

Moyer-In habit of growth, appearance and quality of fruit resembles the Delaware, but we think is a little healthier and more vigorous in growth. Berries a little larger than Delaware. Valuable on account of its earliness.

Price, one year, each, 25 cents; per dozen, $\$ 2.50$. Price, two years, each, 40 cents ; per dozen, $\$ 350$.

Pocklington-Pale green, sometimes with tinge yellow where exposed to sun; bunch large, hard, very compact; berries very large and covered with beautiful white bloom; flesh juicy, sweet, with considerable pulp, and foxy.

Price, one year, each, ro cents ; per dczen. 50 cents; per I00, $\$ 2.00$. Price, two years, each; 15 cents; per dozen, 6 o cents; per Ioo, $\$ 3.00$.

Concord.-Black; early; bunch large, shouldered, compact; berries large, covered with a rich bloom; skin tender, but sufficiently firm to carry well to distant markets if properly packed ; flesh juicy, sweet.

Price. one year, each, ro cents; per dozen, 50 cents; per I00, $\$ 2.00$. Price, two years, each, I2 cents; per dozen, 60 cents ; per 100, $\$ 2.50$.

Delaware-Red ; bunch small, compact ; berriessmall ; skin thin, but firm ; flesh juicy, very sweet and refreshing; of best quality for both table and wine; requires rich soil and good culture.

Price, one year, each, Io cents; per dozen, 60 cents; per Ioo, \$3.00. Price, two years, each, 15 cents; per dozen, 75 cents; per $100, \$ 4.00$.

Empire State - White; bunch medium long, compact; berries medium, quality best.

Price, one year, each 15 cents; per dozen, 75 cents; per Ioo, $\$ 4.00$. Price, two years, each 20 cents ; per dozen, $\$ 1.00$ per 100, $\$ 6.00$. 
Niagara. - White ; bunch very large and handsome ; berries, large, round ; skin thin ; melting, sweet; ripens with Concord.

Price, one year, each, ro cents; per dozen, 50 cents; per I00, $\$ 2.00$. Price, two years, each, 15 cents ; per dozen, 60 cents ; per roo, $\$ 3.00$

Moore's Early.-Black; bunch not quite as large as Concord, but berries larger and very much like it in flavor and quality. Produces a heavy crop. Ripens very early and is nearly out of market before Concord is ripe, and hence brings a comparatively high price.

Price, one year, each, 15 cents; per dozen, 75 cents; per $100, \$ 4.00$. Price, two years, each, 20 cents; per dozen, $\$ 1$ oo ; per roo, $\$ 6.00$.

Worden-Black; bunch large, berries very large, skin thin. It is superior to Concord. It is better in quality, larger berry, ripens five to ten days earlier. In berry it is about the size of Moore's early.

Price, one year, each, Io cents; per dozen, 50 cents; per 100, $\$ 2.00$. Price two years, each, 15 cents ; per dozen, 60 cents; per roo, $\$ 250$.

Wyoming Red.-The earliest good red grape we grow, which has been thoroughly tested; bunch small, skin bright red; fruit sweet; vine a very strong grower; hardy and healthy.

Price, ol1e year, each, 15 cents ; per dozen, 75 cents; per I0o, $\$ 4.00$. Price, two yearrs, each, 20 cents; per dozen, $\$ 1.00$; per roo, $\$ 6.00$.

Lady Washington (White)-Large, late and juicy.

Price, one year, each, 20 cents; per dozen, $\$ 1.50$. Price, two years, each, 25 cents; per dozen, \$2.co.

Lady-An early white grape, hardy and productive; excellent in flavor, very desirable for home use.

Price, one year, each, 15 cents ; per dozen, 75 cents. Price, two years, each, 20 cents ; per dozen, $\$$ r.oo.

Wilder-Black, sweet and pleasant; an early, large grape that has become very popular.

Price, one year, each, ro cents ; per dozen, 50 cents, Price, two years, each, I 5 cents ; per dozen, 60 cents.

Woodruff Red-A large red, handsome grape of the finest appearance; extremely large bunches, ripening early in the season; flavor sprightly and pleasant. The vines are very strong growers. One of the best red grapes we have.

Price, one year, each, 20 cents; per dozen, $\$$ r.25. Price, two years, each, 25 cents ; per dozen, $\$ 2.00$.

\section{FRUIT TREES--APPLES.}

\section{Plant Thirty Feet Apart Each Way.}

The proper season for transplanting fruit trees is during the months of March, April and May, in the Spring. October, November and December, in the Fall, or at any time after the cessation of growth in autumn until they commence budding in the spring. If the ground is not in good condition, it should he made so by the application of a considerable portion of well-decomposed manure or fertilizer of some substantial kind. Most soils would be benefitted by the application of a good coat of lime or wood-ashes, which should be well mixed with the soil. When the ground is prepared, dig the holes sufficiently large to admit the roots. giving them their natural position as near as practicable. Use the surface soil for filling in, having it first well pulverized.

We have a very complete list of all the best varieties, a large and handsome lot of trees, and would request you to send us a list of the stock you are in need of; we think we can please you both in quality of goods and prices. 


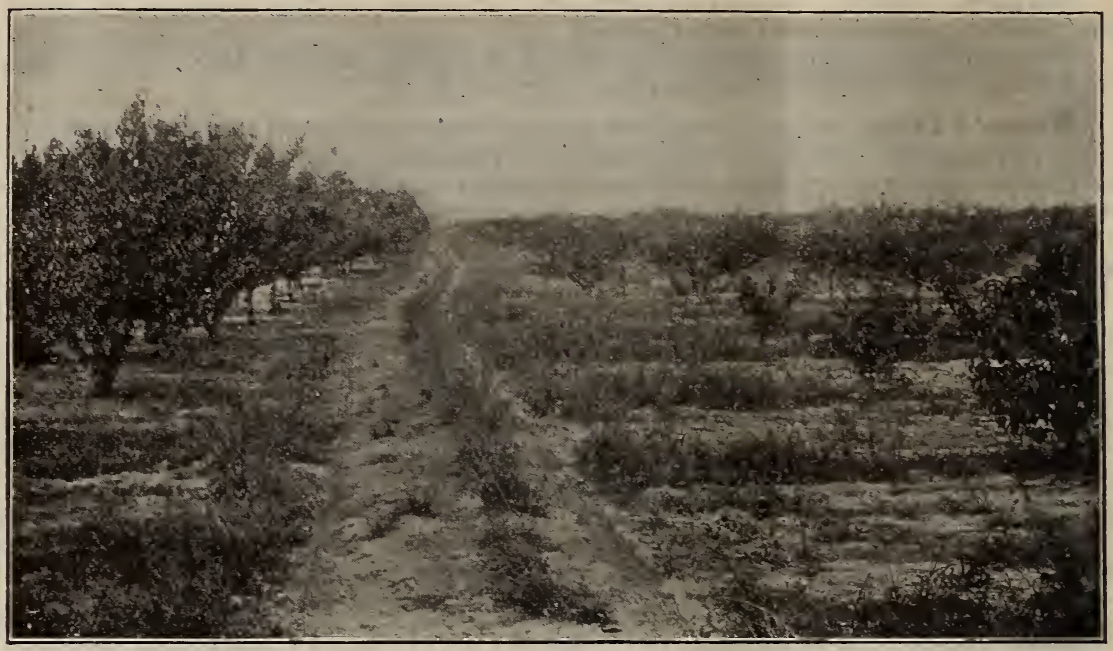

Please note, that we will allow you a discount of ten per cent. on all orders (family lists excepted) to the amount of $\$ \mathrm{I} .00$ and upwards, providing the same reaches us by March $15^{\text {th }}$.

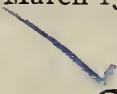

\section{GARFIELD EARLY APPLE.}

Specimens average as large as the Fallawater; color yellow, striped with red, flesh yellow, rich and mellow, sub-acid, melting and luscious. Skin smooth and clean, and not easily bruised. This, together with its good keeping quality. makes it a fine variety for market, and it is unsurpassed in its season for dessert or cooking. Season, last of July to early part of September. Price, each, first class, 30 cents ; per dozen, $\$ 3.00$.

Carlough.-For great beauty of fruit, long keeping qualities and fine growth of tree, this is decidedly without a rival among apples. It is especially valuable, however, as a long keeping, sweet apple, and is by all odds the best of its kind. The fruit is of medium size, oval, smooth and uniform in size and shape. Color bright lemon-yellow, corered with lively crimson, and will keep in good condition without any special care whatever until June. In quality it is of the hest, being sweet, mild, creamy and pleasant. The tree is a most vigorous and beautiful grower.

Price, first-class, each, 30 cents ; per dozen, $\$ 3.00$.

\section{STANDARD VARIETIES AND PRICES.} $\$ 10.00$

No. I, first class stock, $5^{1 / 2}$ to 7 feet, each, 20 cents; per dozen, $\$ 2.00$; per roo,

Extra selected, heavy trees, 7 to 8 feet, each, 25 cents; per dozen, $\$ 2.50$; per IOO, $\$ 15.00$.

Please write us for special prices on lots of $\mathrm{I}, 000$ and upwards, naming the varieties you wish.

Please note that the prices asked for these trees and all other stock named in this catalogue include parking in a thorough manner and delivery to the shipping point. Consider this well when you compare our prices with other dealers who make a separate charge for packing.

We have sereral varieties of apples in stock not mentioned below : 


\section{SUMMER VARIETIES.}

Early Harvest-Medium size; pale yellow, early, mild, excellent, sub-acid.

Red Astrachan-Large, roundish ; nearly covered with deep crimson, overspread with a thick bloom; juicy, and rather acid; a free grower and good bearer; highly esteemed on account of fine appearance; good variety for both orchard and garden.

Yellow Transparent-Size, medium ; lemon yellow, transparent, smooth, waxen surface; flen melting, juicy and of excellent quality. Ripens early, and the tree bears remarkably young; a very valuable and desirable apple. early.

Sweet Bough-Large, pale yellow, sweet, productive; valuable for market;

Early Strawberry-Medium, roundish, handsomely striped with red, excellent productive. hatdy.

Alexander-Large, beautiful red, medium quality, tree a vigorous grower, very

\section{AUTUMN VARIETIES.}

Fall Pippin-Very large, yellow, tender, and best quality.

Gravenstein-Large, bright yellow, roundish, splashed with red and orange, high flavor, prolific.

Maiden's Blush-Medium to large, roundish; clear yellow with pink cheek, beautiful, excellent.

Red Beitigheimer-Very large, beautiful, superior quality ; light yellow, covered with red, purplish crimson when exposed to the sun. Trees are vigorous and healthy growers.

Duchesse of Oldenburg-Medium to large, Russian origin, yellow striped with red, excellent flavor.

\section{WINTER VARIETIES.}

Baldwin-Large, roundish, dark red ; fine flavor, sub-acid, crisp and juicy, very much esteemed. Tree grows erect and vigorous, bearing well.

Ben Davis-Large, bright red; flesh white, juicy, rich and spicy, sub-acid; of good quality ; a popular, good keeping winter variety.

Grimes' Golden-An apple of the highest quality, equal to the best Newtown; medium to large size; yellow, productive.

King (Tompkins County.)-Large, handsome, nearly red; productive, one of the best.

Lady Apple-A beautiful little dessert apple, fruit flat, pale yellow, with a deep red cheek, juicy, rich and pleasant. The fruit sells for the highest price in New York, Philadelphia and Boston.

Lawyer-Large, dark red, covered with small dots, of beautiful appearanee, promises valuable for market.

Mann-Fruit medium to large, roundish, oblate, skin deep yellow when fully ripe, flesh yellowish, juicy, mild, pleasant.

Newtown Pippin-One of the very best apples as to quality. Tree a light grower while young. Very juicy, crisp, and highly delicious flavor.

Northern Spy-Tree very hardy, long lived, good bearer, handsome fruit, and a good variety for market, fruit large, striped with purplish red. 
Rhode Island Greening-Large, green, tender, juicy, and rich, and abundant bearer, one of the most popular varieties for home use and market.

Russet Golden-Medium, clear golden, good bearer.

$\checkmark$ Russet Roxbury-Medium to large, tender, sub-acid flavor, very popular on account of keeping qualities.

Smith Cider-Large, skin yellow, changing to red, flesh tender; juicy, crisp, fair flavor.

Fallowater-Very large, greenish yellow, flesh fine grained, mild, sub-acid, tree vigorous.

Wealthy-Medium in size ; red with white streaks ; good in quality.

Yellow Bell Flower-Large, yellow, rich, sprightly, and of excellent flavor.

Hubbardston Nonesuch-Large yellow apple, striped with red, sweet and rich.

Dominie-Large, greenish yellow, slightly striped with red, of fine flavor, a good bearer and a very valuable apple.

\section{DWARF APPLE TREES.}

We have the following varieties in dwarf trees; these trees are very desirable for those who have but little room to spare for this fruit, and who want some choice fruit in a short time after planting: Red Astrachan, Baldwin, King, Early Harvest, Northern Spy.

Price, each, 25 cents ; per dozen, $\$ 2.50$.

\section{CRAB APPLES.}

No. I trees, 20 cents each; $\$ 2.00$ per dozen.

Hyslop-Large, roundish, deep red with blue bloom, very pretty; flesh yellowish ; excellent for cider and jelly. Popular. Late.

W Lady Elgin-Similar to Lady apple in size and appearance : tender. juicy and good ; an upright, vigorous growth, early and prolific bearer. September and October.

Martha-The trees are rapid, handsome growers, productive of choice fruit, of bright yellow shade, tinged with red; the fruit is of good fair size. Very desirable variety.

\section{PEAR TREES.}

\section{Plant twenty feet apart each way.}

Pear trees prefer a rich, heavy soil ; still on light soils made rich by the use of fertilizers, the fruit is of the best quality. The branches should be thinned out occasionally; most varieties require heading back, especially when trees are young.

The fruit is much improved if picked before it is ripe ; it never should be allowed to ripen on the trees. The fruit of winter varieties should be left on the trees as long as possible, then stored in a cool, dry cellar, and removed to a warm room for ripening as wanted.

We have the largest and finest stock of pear trees we have yet had; we have made our prices very low on this account, and hope to dispose of our stock early in the season Should you contemplate planting largely of this profitable fruit, please send us a list of the varieties you need, when we will send to you our lowest estimate by return mail. 


\section{VALUABLE NEW VARIETIES.}

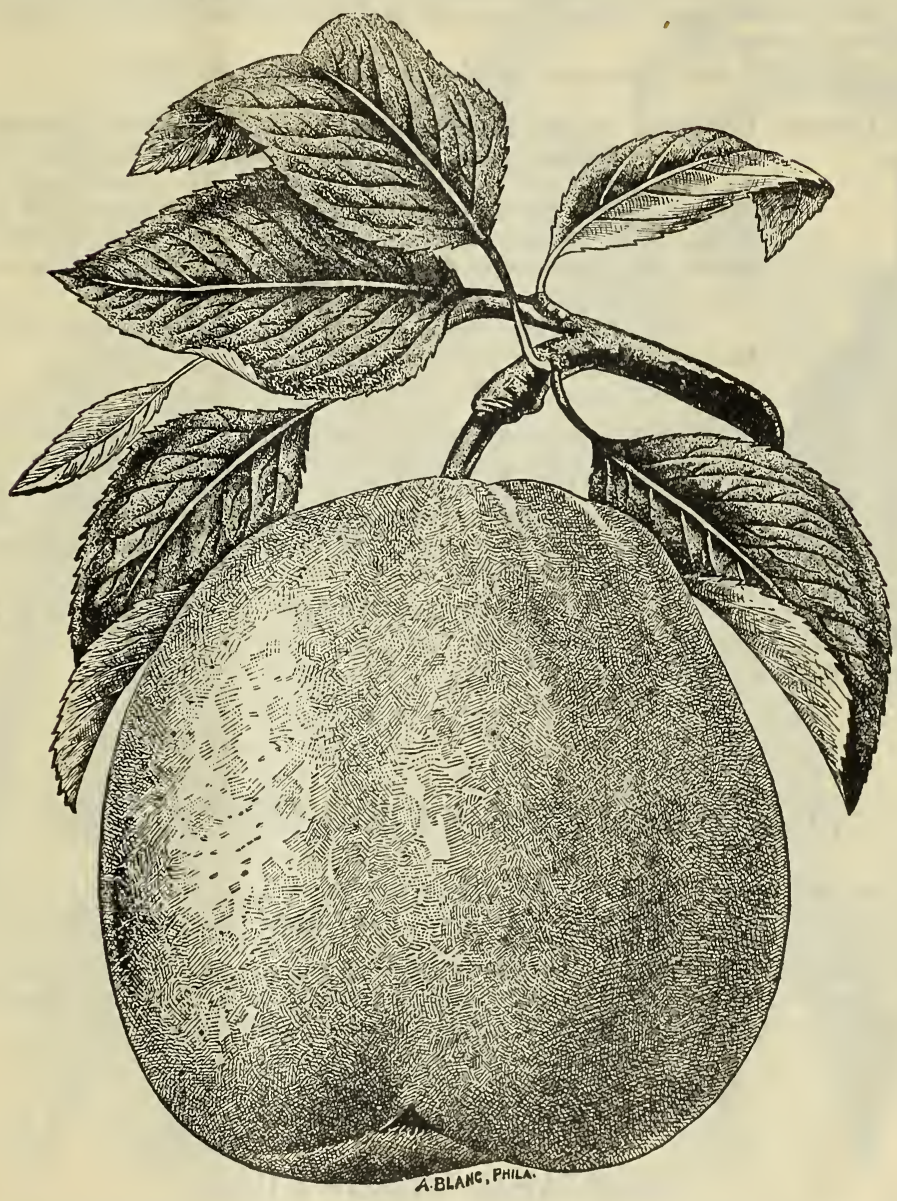

Koonce-The Koonce originated in Illinois, where the original tree has been standing for many years. It is exceedingly early; in fact the entire crop is marketed before the early harvest. The Koonce is not only early, but it is of fine quality. Most early pears rot at the core, and do not ship well, but the Koonce is an excellent shipper. It can be picked green and will color up beautifully in a few days. The fruit is medium to large, very handsome; surface yellow, one side covered with a bright carmine, containing brown dots; stem meaty and short; quality very good, spicy. juicy and sweet. Far ahead of any other early pear. $\$ 7.50$.

Trees 3 to 4 feet., each, 6oc.; dozen, $\$ 6.00$. Trees 4 to 5 feet, each, $75 \mathrm{c}$.; dozen,

\section{IDAHO PEAR.}

The trees are good, thrifty, strong growers.

"Size of fruit, from 4 to $4 \frac{1}{2}$ inches in diameter; shape a little flattened, tapering slightly both ways from the center, quite irregular, depressed at the stem; surface rough and uneven, yellow or straw color, with a faint blush or brownish red on the sunny side and a few bronzed blotches; dots minute, dark and very numerous; basin deep, flaring, very irregular or ribbed, and thickly covered with fine brown dots; 
cavity medium, abrupt, irregular; stem stout and rather long; core very small; seeds few ; flesh almost white, fine-grained, buttery; melting, lacks the grit so often found in pears ; flavor sweet to mild, sub-acid, rich and aromatic, juicy; quality very good ; season September."

Price, first-class, each, 30 cents ; per dozen, $\$ 3.00$; per $100, \$ 25.00$.

The Lincoln Coreless Pear-The trees are strong. healthy growers--grow

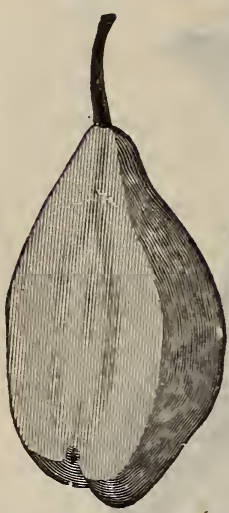
heavy and stocky-enabling them to hold the fruit well. No seeds, no core, large size, quality the best of its season, good keeper, good shipper. Think of eating one and a half pounds of truly delicious pear without having to be bothered with the core, which often lakes up one-fourth of the fruit itself. It would be an excellent pear to preserve whole, or to eat as dessert fruit. $\$ 6.00$.

Price, first-class trees, 4 to 6 feet, each, 75 cents; per dozen,

Wilder-It is one of the earliest of all early pears to ripen. Therefore it will sell at a fancy price at the fruit stands. There is no early pear to compete with it. A good grower, good keeping, good shipping, superior flavored, early pear is what is needed at this moment in our homes and on the market, and the Wilder Early appears to fill the bill.

Price, first class trees, 5 to 6 feet, each, 50 cents; per dozen, LINCOLN CORELESS. $\$ 4.00$; per 100, $\$ 30.00$.

\section{STANDARD VARIETIES AND PRICES.}

We can furnish any of the varieties hereafter named.

First-class trees, 2 years, 5 to 6 feet, each, 25c.; dozen, $\$ 3.00 ; 100, \$ 15.00$. (Prices per 500 and $\mathrm{r}, 000$ given on application).

We have a very fine lot of extra heavy fruiting trees, 3 years old, 7 to 8 feet in height. Very desirable trees for those who are anxious to get fruit as soon as possible at the following prices: Each, 50 cents ; dozen, $\$ 5.00$; 100, $\$ 35.00$.

\section{SUMMER VARIETIES.}

Lawson-One of the most beautiful when full ripe, a brilliant crimson, yellow ground; flesh is rich, juicy and pleasant.

$\checkmark$ Clapp's Favorite-Large, delicious, good grower, productive. Ripens in advance of Bartlett; rots unless picked early. Hid-summer.

Osband's Summer-Medium, yellow with red cheek; half melting, mild and pleasant; fine flavor and excellent. Productive.

Doyenne d'Ete-Small, nearly round; yellow, with red cheek; a good, juicy, sweet pear; tree vigorous and productive. One of the very earliest varieties.

\section{YOU CAN SAVE TEN PER CENT.}

We will allow you a discount of ten per cent. on any order to the amount of $\$ 1.00$ and upward, provided the same reaches us before March I5th. (We canuot allow this discount on the Family Lists named in this catalogue.) 


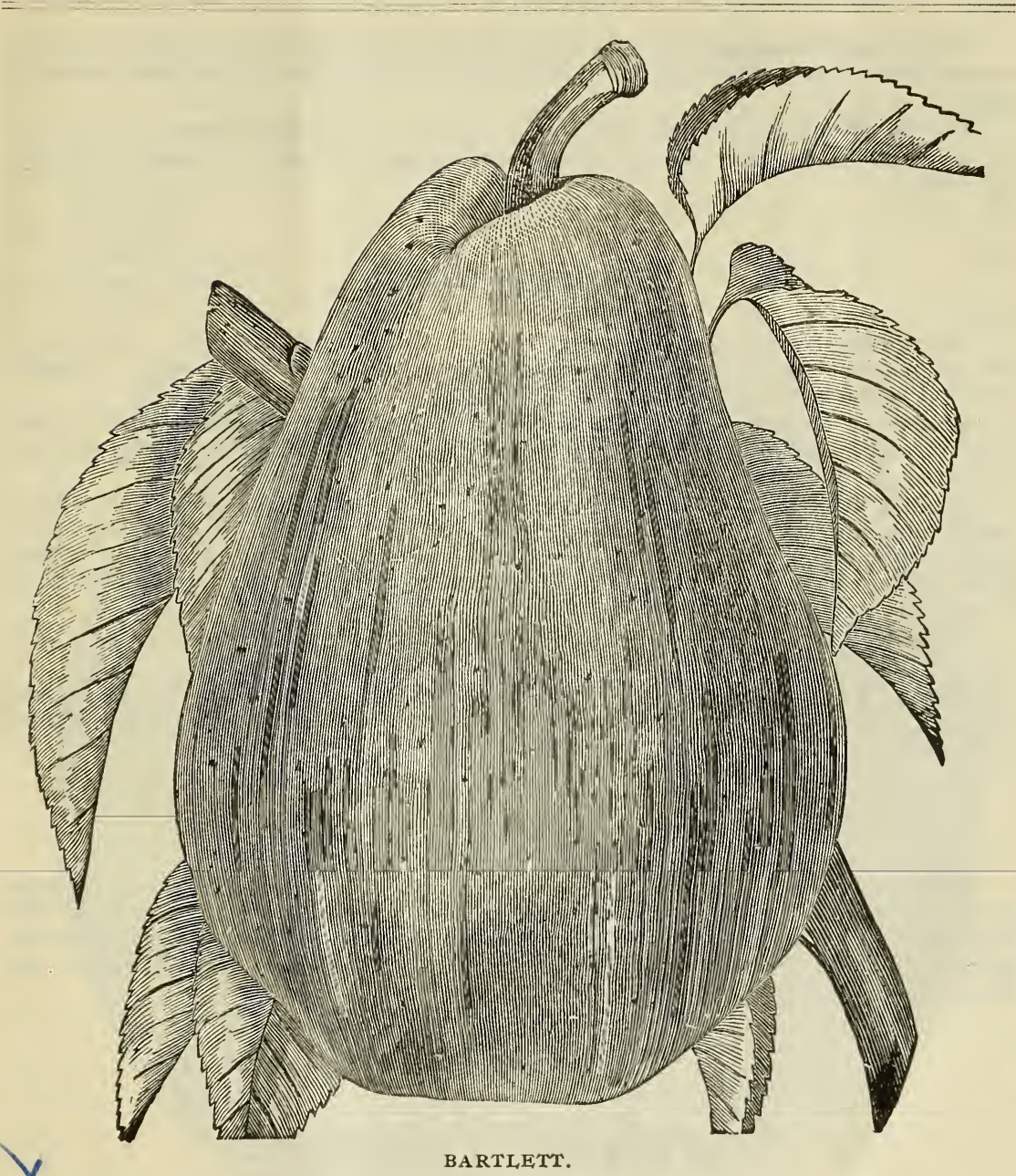

Bartlett-Large, clear yellow, juicy, buttery, excellent, thrifty, young, heavy, and regular bearer; very reliable and popular. Late summer.

\section{AUTUMN VARIETIES.}

Kieffer's Hybrid-This new pear, said to be blight-proof by a number of parties who have grown it for many years, is certainly very free from blight, if not strictly " blight-proof." It is immensely productive, and begins to bear very early, and is of large size and very handsome.

Beurre Bosc-Large and fine russety yellow, flesh white, melting, juicy and sweet, productive.

$\checkmark$ Sheldon-Medium size, greenish russet, melting and juicy, highly aromatic flavor. Should be largely planted.

Seckel-One of the richest pears grown; usually very productive, fine grained, sweet and exceedingly juicy. 
Duchesse D'Angouleme-One of the largest of all our pears, greenish yellow, spotted with russet; flavor good. Its large size and handsome appearance makes it valuable for market.

Flemish Beauty-A large, beautiful, sweet pear. Tree good bearer.

Howell-Large, light waxen yellow, with a fine red cheek. An early and profuse bearer.

\section{WINTER PEARS.}

Clairgeau-Very large, yellow and red, handsome and attractive; flesh yellowish, keeps sound a long time. Tree a good grower and abundant bearer. A magnicent and valuable market fruit.

$\checkmark$ Lawrence-Medium yellow, covered with round dots; somewhat buttery, with a rich flavor. Should be in every orchard and garden; tree healthy, hardy and productive.

Beurre D'Anjou-A large, handsome pear, greenish, sprinkled with russet; flesh white, buttery, with a high, rich flavor, very productive. We have no hesitation in pronouncing it to be the most valuable pear that growers can raise. Every garden should have one or more of this pear. Keeps until the Winter holidays, when it commands very high prices in the market.

President Drouard-A very good looking and large Winter pear, with a delicate and abundant perfume. Melting and juicy.

Winter Nelis-Medium size, green and russet; fine grained, and when well ripened is one of the best. We have eaten this pear in March and considered them delicious.

\section{DWARF PEAR TREES.}

Plant the Dwarf trees eight feet apart each way. We have the following varieties in the dwarf trees, and we would recommend them to all who are anxious to get fine large fruit in a short time: Duchess, Bartlett, Beurre D'Anjou, Clapp's Favorite, Kieffer, Sheldon, Seckel. Price for No. I trees, 4 to 5 feet, each, 20 cents ; per dozen, $\$ 2.00$; per hundred, $\$ 15.00$.

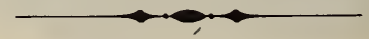 \\ PEACH TREES.}

\section{Plant The Trees Twenty Feet Apart Each Way.}

Peach trees will not give good results in the orchard without thorough cultivation but set around and near buildings, in sheltered nooks, will live much longer and give greater satisfaction, and, singularly enough, thrive better if the ground about them is not disturbed.

Be sure that the soil is well supplied with potash. Muriate of potash is the most desirable form to apply. Wood ashes may be used to a good purpose if readily obtainable. Bone dust and ashes is one of the best fertilizers.

Plant no deeper than the trees stood in the nursery, and make the soil very firm. It is very important that the young tree should be properly pruned at the time of planting. All side branches should be cut back to within a few inches of the main stem, the latter being severed at about two-thirds the distance from the ground. Small trees should be pruned to a whip, cutting back the stem nearly one-half the way to the ground. The after culture is very simple, being merely to keep the surface always mellow and free from weeds. For the first two years after planting, hoed crops may be planted between the trees with advantage. 


\section{WELL KNOWN VARIETIES AND PRICES.}

Please remember the prices we quote below include packing and delivery to shipping point. Consider this when comparing our prices with those of others.

First class, 5 to 6 feet, each, 20 cents; per dozen, $\$ 1.75$; per hundred, $\$ 8.00$; per thousand, $\$ 65.00$.

Medium, 4 to 5 feet, each, I5 cents; per dozen, $\$ \mathbf{I} .50$; per hundred, $\$ 7.00$; per thousand, $\$ 60.00$.

Second class, 3 to 4 feet, each, I 2 cents; per dozel1, $\$ 1.25$; per hundred, $\$ 6.00$; per thousand, $\$ 50.00$.

Extra fine trees, selected and heavy, 6 to 7 feet, each, 25 cents; per dozen, $\$ 2.50$.

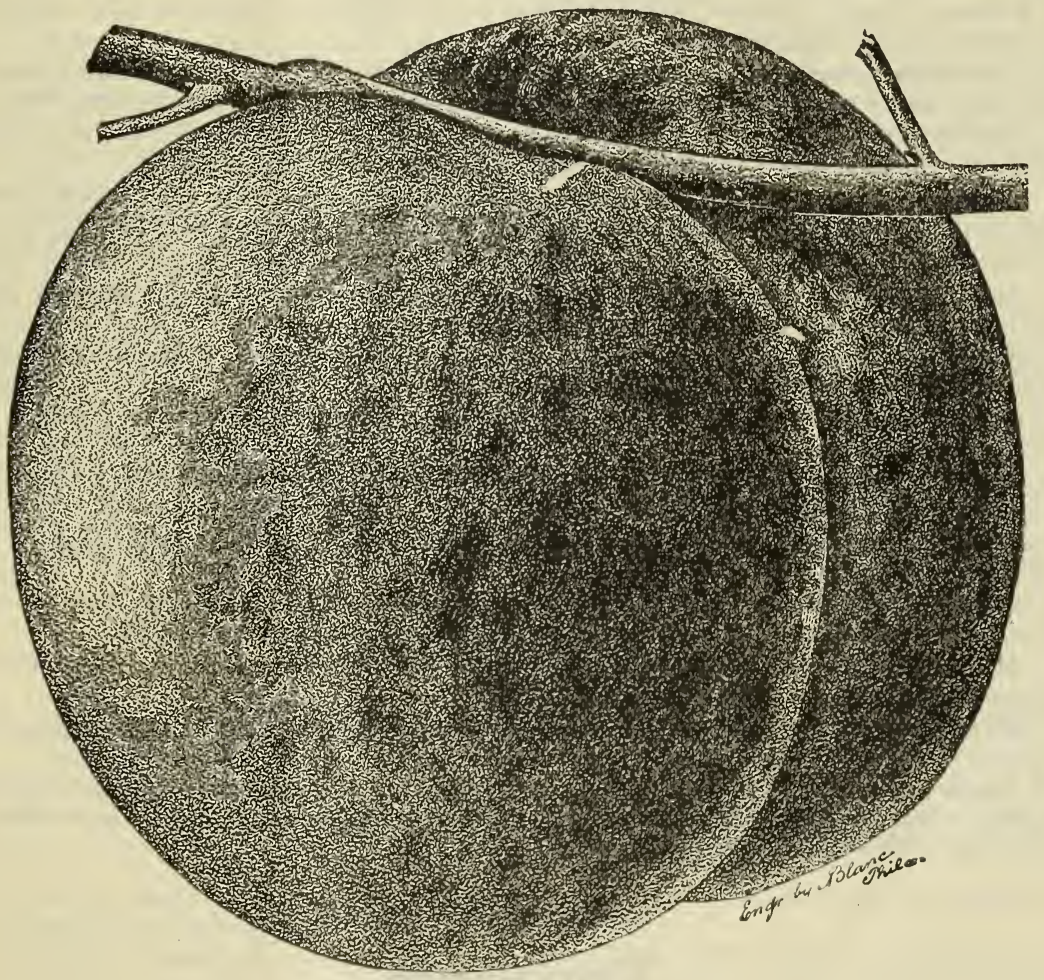

\section{RELIABLE STANDARD VARIETIES.} July.

Alexander-Very early, size good, handsome and regular in form, freestone.

Crawford's Early-Very beautiful, and the best yellow peach for market purposes ; fruit very large, oblong; skin yellow, with fine red cheek; flesh yellow, juicy, sweet and excellent; wonderfully productive. Last of August.

Elberta-Large, yellow with red cheek, juicy and of high quality ; flesh yellow and melting. A very valuable sort. September.

(Beer's) Smock-Fruit medium to large; skin light orange; yellow mottled with red; some specimens dry, others moderately juicy, rich, a good late market sort. 
Crosbey-The fruit is of medium size, roundish in form, slightly flattened, with a distinct seam on the blossom end; bright orange yellow, splashed with streaks of carmine on the sunny side, of beautiful appearance. It ripens between Early and Late Crawford.

Lovett's White-A very late white peach, claimed to have all the merits of the well known Late Heath Cling, with the additional merits of becoming a freestone and handsomer, hardier, of better quality, and a more abundant and regular bearer, season late, color pure white, very large, flesh firm and sweet.

Wonderful-A new variety, color rich, golden yellow, largely overspread with carmine; one of the latest freestone varieties; of large size, possessing remarkable keeping qualities; wonderfully productive. We think it possesses great merit, and should be planted in every orchard.

Salway-Large; yellow, mottled with a red cheek; a valuable late variety, ripening ten days after Smock.

Lord Palmerston-A maynificent, very late peach ; cling. Enormously large, beautiful creamy white with a blush cheek; rich flavor and firm, but melting flesh.

Crawford's Late-Fruit of the largest size; skin of greenish yellow, with dull red cheek ; flesh yellow ; one of the finest late sorts. Last of September.

Globe-A very rapid grower and an enormous bearer; fruit very large ; flesh firm, juicy ; yellow, shaded with crimson, very rich, lucious. September and October.

Hale's Early-Medium size; smooth, white, delicately marbled with bright skin.

Keyport White-Medium to large; pure white; white flesh through to the stone. Tree a good grower, productive and valuable.

Mountain Rose-One of the best and most reliable peaches ; large, white ; flesh white, sweet; productive. Early August.

Morris White-Medium; straw colored, tinged with red; delicious and very juicy, productive.

Old Mixon Free-Uniformly large; white, covered with bright red; one of the best and most reliable. Last of August.

$\checkmark$ Pride of Franklin-Yellow flesh; peach similar to Crawford Late, said to be larger and a few days later.

Stevens' Rareripe-Large; fruit resembles an enlarged Old Mixon Free; of the highest color and very beautiful; very productive and free from all disease.

Stump the World-Very large; skin white, with bright red cheek ; flesh white, juicy and good. Last of September.

Ward's Late-Large; white, with red cheek; rich, sprightly and lucious; a valuable late market variety.

Fox's Seedling-A very valuable peach, ripening at a time that makes it desirable aside from its large size, fine quality, good shipping quality and market value ; white flesh, freestone, beautiful red cheek.

\section{APRICOT.}

\section{Plant Eighteen Feet Apart Each Way.}

The apricot requires about the same treatment as the plum to succeed, and is subject to the same enemies.

Price for any of the varieties named below, 5 to 6 feet trees, each, 35c., doz. $\$ 3.00$.

Acme-It is a fine grower, with large, handsome, thick foliage, and an early bearer of large and good fruit. Better than any Russian sort I have seen in this country. Fruit yellow, with red cheek.

Breda-Small, ronnd, orange flesh, juicy, rich and vinous; hardy and a good bearer. July to August.

Moorpark-Very large; orange, with a reddish cheek; flesh orange, sweet, juicy, with a fine flavor; a very valuable variety. Beginning of August. 


\title{
CHERRY TREES.
}

\author{
Plant Twenty-five Feet Apart Each Way.
}

(Sweet).-The cherry thrives on any good land that is not excessively wet, and is naturally a hardy tree, succeeding in lightest soil and dryest situations. The Heart and Bigarreau varieties are of rapid growth, with large, glossy leaves, forming fine, pyramid shaped heads, and producing large crops of luscious fruit; are well adapted for planting along the streets, or in yards as shade trees.

\section{NEW VARIETIES.}

Mercer Cherry-It is larger than the Black Tartarian and finer flavored. It is a splendid shipper and always brings the highest prices in the market. In I89I there was a glut in the cherry market, but we cleared $\$ 2.00$ per basket, and one tree yielded between thirty and thirty-one baskets of fruit. In ISgo we had more cherries on our tree than was picked from any other two trees in the neighborhood, and they netted us over $\$ 2.50$ per basket (sixteen quarts).

In 1892 it again proved its superiority over all other varieties by producing a full crop of fruit, free from worms or rot, while other varieties were totally destroyed by rot.

Price for trees, 6 feet and up, 50 cents ; per dozen, $\$ 5.00$.

Centennial_-Comes highly recommended as the best shipping cherry ever known. The fruit is of immense size; beautiful amber-shaded red, with very firm yet tender flesh; sweet, rich and luscious. It is a seedling of Napoleon Bigarreau, which it resembles in appearance, but is much larger. Early.

First-class trees, each, 50 cents; per dozen, $\$ 500$.

Windsor-The tree is vigorous, hardy and an early and good bearer. The cherries are obtuse heart-shaped, dark purple or nearly black; the flesh quite firm, fine in texture and rich in flavor, ripens early.

Three years, 7 to 8 feet trees, each, 50 cents ; per dozen, $\$ 5.00$; per 100, $\$ 30.00$.

\section{STANDARD VARIETIES.}

Please note that the prices asked below include packing in a thorough manner and delivery to shipping points. Price for all vaieties enumerated below, as follows :

Trees, 5 to 6 feet, each, 25 cents; per dozen, $\$ 2.50$; per hundred $\$ 12.00$. We have a very fine stock of choice, selected extra heavy trees 7 to 8 feet in height, clean stocky and well branched at 50 cents each ; per dozen, $\$ 5.00$; per I00, $\$ 25.00$.

\section{HEART AND BIGARREAU-SWEET.}

Black Eagle-A fine, large, black cherry, of first rate quality and productive; very sweet and rich; one of the best. First of July.

Black Tartarian-Very large, purplish black, half tender; flavor mild and pleasant. Ripe last of June and beginning of July. One of the most popular varieties in all parts of the country.

Coe's Transparent-Medium size, pale amber, red and mottled next the sun; tender, sweet and fine, one of the best. End of June.

$\checkmark$ Downer's Late-Rather late, light red, tender and juicy, slightly bitter before fully ripe.

Y Gov. Wood-The finest of Dr. Kirtland's seedlings, of Ohio, clear, light red, tender and delicious. End of June.

Napoleon-A magnificent cherry of the largest size, pale yellow with a bright red cheek, flesh very firm, juicy and sweet, ripens late.

Rockport-Large, pale amber in the shade, light red in the sun; half tender, sweet and good. Ripe same time as Black Tartarian.

Yellow Spanish-Large, pale yellow, with a bright red cheek in the sun, flesh firm, juicy and delicious. End of June. 


\section{DUKE AND MORELLOS-SOUR.}

\section{Plant Fifeeen Feet Apart.}

Price for any of the varieties named below:

Trees 4 to 5 feet, each, 25 cents; per dozen, $\$ 2.50$; per hundred, $\$ 2.00$.

* Heavy three year fruiting trees, each, $50 c$.; dozen, $\$ 5.00$.

Belle Magnifique-Fruit large, red, late; excellent for cooking and fine for canning, rather acid.

Early Richmond-Medium size, dark red, melting, juicy, sprightly, acid flavor.

Empress Eugenie-Fruit large, dark red, very rich, tender and sub-acid. A superior variety.

English Morello-Medium to large, blackish red, rich, acid, juicy and good, very productive. Very late.

Large Montmorency-A large, rich, acid cherry; larger than Early Richmond, and fully ten days later.

Late Duke-Large, light red, late and fine.

May Duke-Large, dark red, juicy and rich, an old excellent variety, productive.

Reine Hortense-Very fine, large, bright red, juicy and delicious, productive.

\section{PLUMS.}

\section{Plant Twenty Feet Apart Each Way.}

The plum shows its best production when planted on heavy, well-drained and rich soil. To secure fine fruit it is necessary to be guarded against the curculio, a small brown insect, which stings the fruit, causing it to fall before maturity. To guard against this insect the trees should be jarred each morning early, while the dew is yet on. Spreading sheets under the trees, insects falling on them can be easily discovered and killed. Fallen fruit should be burned or fed to swine. As soon as blossoms have fallen, continue for two weeks. The cost of protecting large orchards will not exceed ten cents per tree for the entire season.

\section{JAPAN VARIETIES.}

These are somewhat different from our American sorts, being of much more vigorous growth; they are very productive, and the fruit can be shipped a long distance and arrive in splendid condition. Their chief value is the fact of their coming into bearing a short time after being planted.

Price for any of the varieties named (all on Plum stock) trees, 5 to $6 \mathrm{feet}, 30 \mathrm{c}$. each; $\$ 3.00$ per doz.; Ioo for $\$ 15.00 ;$ trees, 7 to 8 feet, $50 c$. each; $\$ 5.00$ per doz.; Ioo for $\$ 25.00$.

Abundance-It is exceedingly hardy. Its propensity for early bearing is such that before it leaves the nursery row the limbs bend with the weight of fruit until they sometimes break, and this is the case every year-the curculio having no effect upon it; the fruit is large, showy and of a beautiful amber shade.

Satsuma-A purple fleshed plum from Japan, of very vigorous growth, with rank, dark green foliage ; enormously productive of fruit ; large and handsome. Pit but little larger than a cherry stone. Fruits at two or three years of age. Considered the most valuable of Japan plums.

$\checkmark$ Burbank-The fruit is usually from five to five and a half inches in circumference, and varying less in size than other Japan plums, nearly globular, clear cherryred, with a thin lilac bloom. The flesh is a deep yellow color, very sweet, with a peculiar and agreeable flavor.

Ogon-A handsome, very desirable Japanese plum. Large, nearly round, of a bright yellow with faint bloom ; flesh firm, sweet, rich and dry. Excellent for canning. Last of July. 


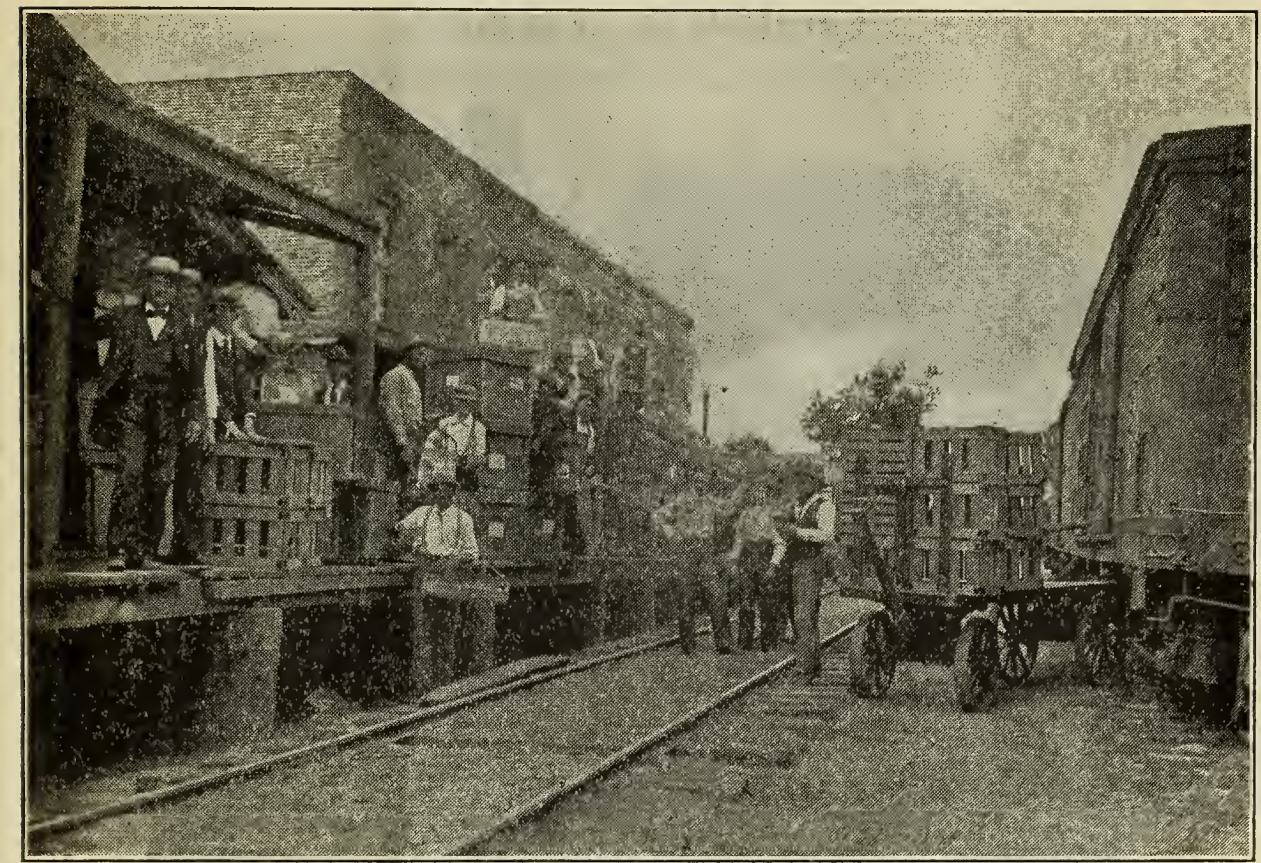

A SHIPPING SCENE.

\section{LIST OF EUROPEAN VARIETIES.}

\section{(All on Plums.)}

Price for any variety enumerated below. Trees $51 / 2$ to 7 feet, 30 cents each, per dozen $\$ 3.00$; per 100, $\$ 15.00 ; 3$ year fruiting trees heavy and fine, each, 50 cents; per dozen, $\$ 5.00$; per 100, $\$ 25$ oo.

Please note that these prices include packing. We have a very large and fine stock of plums, and have made our prices low for first-class stock.

Spaulding-It ripens early, from middle to last of August. The fruit is large, yellowish green with marblings of a deeper green, and delicate white bloom; flesh pale yellow, exceedingly firm, of sugary sweetness.

Lombard-Medium, round, oval ; violet-red; juicy, pleasant and good ; adheres to the stone; productive. A valuable market variety.

$\checkmark$ Niagara-Very large ; reddish purple, entirely covered with gray bloom; flesh deep greenish yellow.

Reine Claude-A large fine variety ; skin greenish yellow, covered with a thick bloom ; flesh yellow, juicy, melting, rich.

Richmond-Fruit medium size, oval, reddish purple; flesh juicy, sugary, greenish yellow, good.

Shipper's Pride-Large, round, purple; very firm, excellent quality. Very productive.

Shropshire Damson-The flesh is amber colored, juicy and sprightly. Commands a high price; it is enormously productive.

Bradshaw-Early; dark violet-red, juicy, sprightly. Tree vigorous, productive.

Green Gage-Small; considered the standard of excellence. Mid-season.

v German Prune-Fruit oval in shape, nearly two inches long, of good quality and much esteemed; hangs on the tree, and is firm. sweet and pleasant.

Imperial Gage-Rather large, oval, greenish ; flesh juicy, rich delicious; a good grower; ripens early.

Yellow Egg-Large, oval, yellow, juicy, rich, vigorous, productive. Early. 


\section{QUINCE TREES.}

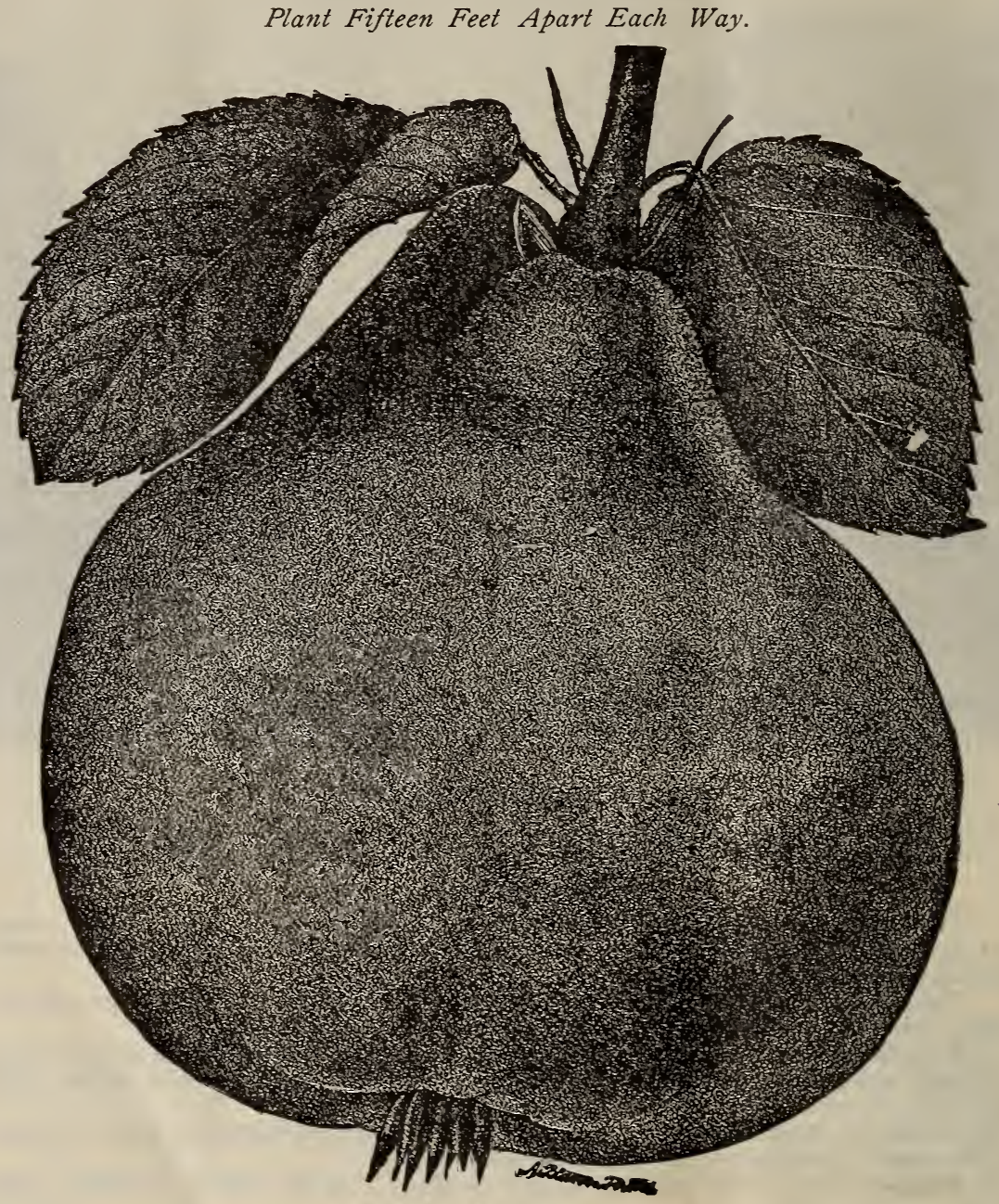

THE FULLER QUINCE.

"Fruit large to very large, distinctly pyriform, often with a very abrupt and small neck; the surface somewhat rigid, the skin assuming a rich yellow color early in the season; calyx set in a deep, wide basin; flesh remarkably tender and well flavored. The quince is a most showy tree in both flower and fruit, and the Fuller will be especially valuable to plant for ornament on account of its exceptionally large and brilliant fruit."

Price, first-class trees, each, 75 cents; per dozen, $\$ 7.00$.

\section{STANDARD VARIETIES.}

Meech's Prolific-A vigorous grower, and immensely productive, frequently bearing fruit when but two years of age, increasing in quantity yearly to such an extent as to require vigorous thinning to prevent injury to the tree from overbearing. The fruit is large, lively orange color, of great beauty and delightful fragrance. Its cooking qualities are unsurpassed.

Price, for trees 4 to 5 feet, each, 35 cents; per dozen, $\$ 3.50$; per hundred, $\$ 20.00$. 
Rea's Mammoth-A superb fruit, much larger than Orange, but of the same form and color. Tree healthy, very thrifty grower, productive.

Price of above trees, 4 to 5 feet and stocky, each, 35 cents; per dozen, $\$ 3.50$; per hundred, $\$ 20.00$.

Champion-Fruit averages larger than Orange, more oval in shape, quality equally fine, and a longer keeper; a splendid quince. October and November.

Price for trees 4 to 5 feet, each, 25 cents; per dozen, $\$ 2.50$; per hundred, $\$ 15.00$.

Orange-Large, roundish, bright golden yellow, cooks tender and is of very excellent flavor. October.

Price, for trees 4 to 5 feet each, 25 cents; per dozen, $\$ 2.50$; per hundred, $\$ 15.00$.

\section{MULBERRIES.}

Downing-The finest variety introduced, yielding large quantities of fruit from July to Autumn. Very desirable for lawn planting or as a shade tree, forming a dense shade, a rapid grower.

Price of No. I trees, each, 50 cents ; per dozen, $\$ 5.00$.

\section{NUT TREES.}

Nut tree planting has become very popular of late and there is a brisk demand for the trees. We have been importing annually over two million dollars worth of nuts, that we have learned of late years can be grown just as easily in our own country. The trees should be planted, pruned and cultivated nuch the same as we treat our fruit trees.

\section{CHESTNUTS.}

Success on two year heads, $\$ 2.50$ each. Parrys Giant on two year heads, $\$ 2.50$ each.

Paragon-This variety has become very popular of late and to our own knowledge is being planted quite extensively. The tree is a rapid, strong, vigorous grower, and comes into bearing a short time after being planted. It is productive of large nuts ; the flavor is very good.

Price, each, 2 year, 3 to 4 feet, $\$ 1.25$; per dozen, $\$ 12.00$.

Numbo-A hardy productive variety of European origin, but seems well adapted to this climate. It ripens early, nuts are large and of good quality.

Trees grafted 3 to 4 feet, each, 75 cents; per dozen, $\$ 7.50$.

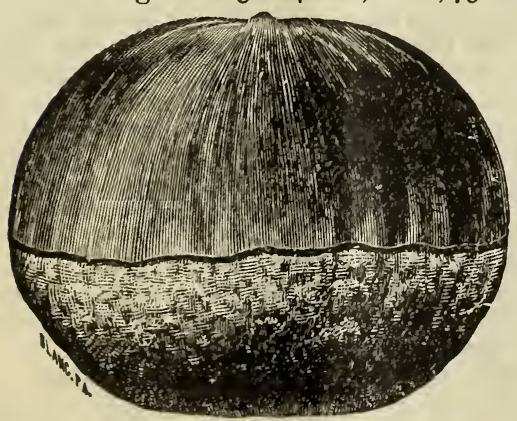

JAPAN GIANT CHESTNUT.

chestnut of the forest. In sweetness and delicacy of flavor or as a shade tree, unsurpassed.
Japan Giant Chestnut-The tree is decidedly ornamental, hardy and productive, of dwarf habit, bearing extremely young. Nuts of enormous size,

American or Sweet-The well known

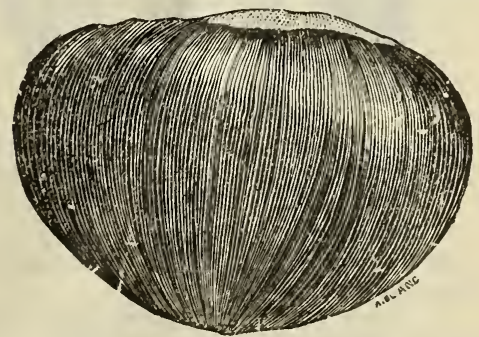

SPANISH CHESTNUT. 
Spanish Chestnut-A very hardy, productive nut and becoming more popular each year.

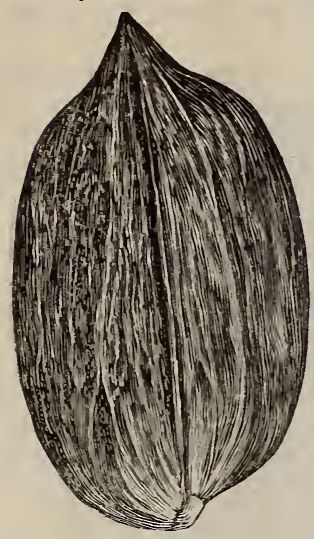

PECAN NUT.

Pecans-The pecan bears oblong, smooth, thin-shelled nuts, with sweet and delicious kernels. The nuts are very desirable for family use, or valuable for market.

English Walnut-It is a profitable tree to plant, as it produces large crops of excellent nuts, and the large quantities of ripe nuts that are annually imported and sold here, prove the estimation in which they are veld for the table.

English Filbert or Hazelnut-Nut nearly round, rich and of excellent flavor, admired by all for the dessert.

Price for any of the six varieties named above, firstclass trees, each 35 cents; per

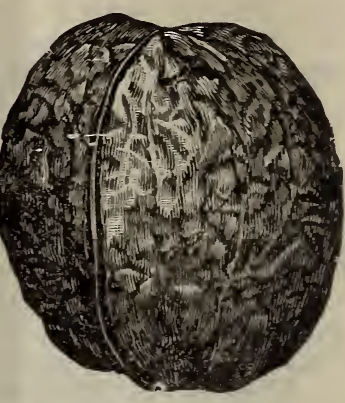

ENGLISH WALNUT. dozen, $\$ 3.50$; per hundred, $\$ 20.00$.

\section{GARDEN ROOTS.}

\section{ASPARAGUS PLANTS.}

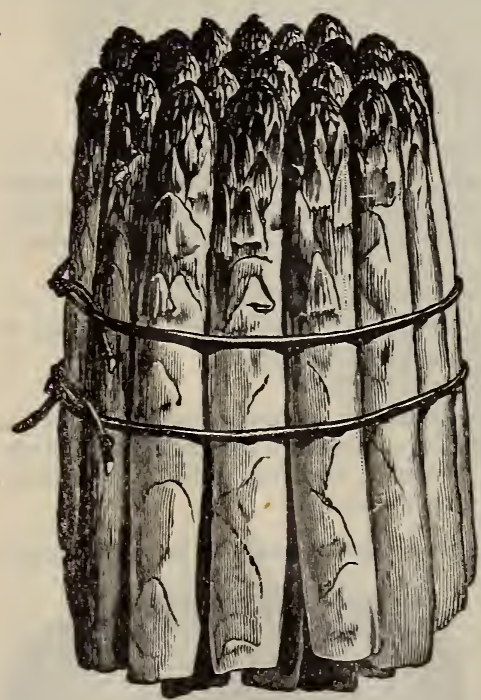

We have a fine, strong, large stock of the varieties named; our plants grown on good soil, such as we have here in Orange County, are nearly twice the size of those grown by the majority of dealers.

After preparing the ground thoroughly, and freeing it from all stones, roots or other rubbish, plant for garden culture, three feet apart between the rows, and one foot apart in the rows ; for field culture set the plants four feet apart between the rows and eighteen inches apart in the rows. In either case be sure to set them one foot below the surface of the ground, covering the plants not more than three inches deep; every ten days or so after, or as the leader shows over the soil, fill in again, and use this method of covering until the leader is above the surface of the ground. Many failures of plants to grow, that have wrongfully been charged to the inferiority of the plants, have been caused by the planting in these deep trenches and filling in over the plants level with the surface ground at the time of planting, the plants decaying in the ground for want of air, because of this deep covering; then let it be remembered that while it is of the first importance to get the roots deep in the ground, it should be accomplished in the manner described above.

Write to us for prices on 5,000 to 50,000 lots. Our stock is very fine and large.

Palmetto-A valuable new variety, and is being planted very largely, It is nearly twice the size of the Conover, fully as early, and as productive. The flavor is excellent.

Price, two year plants, per dozen, 30 cents; per I00, 80 cents; per $1,000, \$ 5.00$. Price, one year plants, per dozen, 25 cents, per Ioo, 50 cents; per I,000, $\$ 3.50$. 
Barr's Mammoth-A variety that comes highly praised. Said to be nearly double the size and much more productive than Conover's Colossal. We have a large stock of this variety.

Price, two year plants, per dozen, 30 cents; per IOo, 80 cents; per I,000, $\$ 5.00$; Price, one year plants, per dozen, 25 cents ; per Ioo, 50 cents ; per I, Ooo, $\$ 3.50$.

Conover's Colossal-The old standard and popular variety, a good producer; of large, quick growth and superb in quality.

Price, two year plants, per dozen, 25 cents; per Ioo, 60 cents; per I,000, $\$ 4.00$. Price, one year plants, per dozen, 20 cents ; per IOO, 50 cents ; per I,000, $\$ 3.00$.

PLEASE NOTE.-That we have nearly one-half million of asparagus plants, one and two-year-old plants, in the varieties heretofore named. Our plants are grown on good, rich land, and with great care, consequently, they are fine, large, vigorous plants. We have made the prices for these plants very low, however; if you are going to plant for market purposes in a large way, and can use 5,000 or more plants, please write us for a special low price. We will answer you by return mail.

\section{RHUBARB.}

(Commonly known as Pie-plant).--It is a very valuable vegetable and should be planted in every garden. It is easy of cultivation, and a few plants will furnish the family (and neighbors) with a healthful fruit for pies and other purposes before the apple even shows its blossoms.

Victoria and Myatt's Linnæus, each, Io cents; per dozen, $\$ 1.00$; per 100, $\$ 4.00$.

\section{HORSE RADISH.} $\$ 5.00$.

Sets-Per dozen, 25 cents; per I0o; 80 cents; per I,000

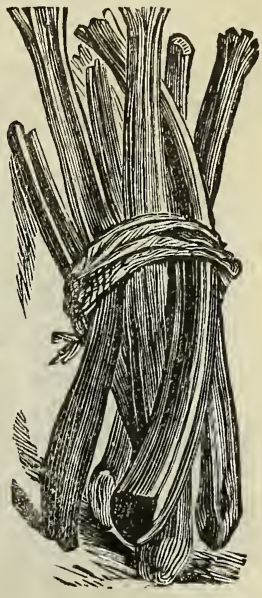

MYATT'S RHUBARB.

\section{E. FRANK COE'S FERTILIZERS.}

\section{(FREIGH'T PREPAID.)}

Please remember that the prices quoted below include all freight and transportation charges, and are for any of the grades of the E. Frank Coe Fertilizers delivered at your railroad depot or boat landing. No discount on these prices.

\section{Price List of Different Brands.}

E. Frank Coe's High Grade Ammoniated Bone Sub-phosphate, in Per Ton.

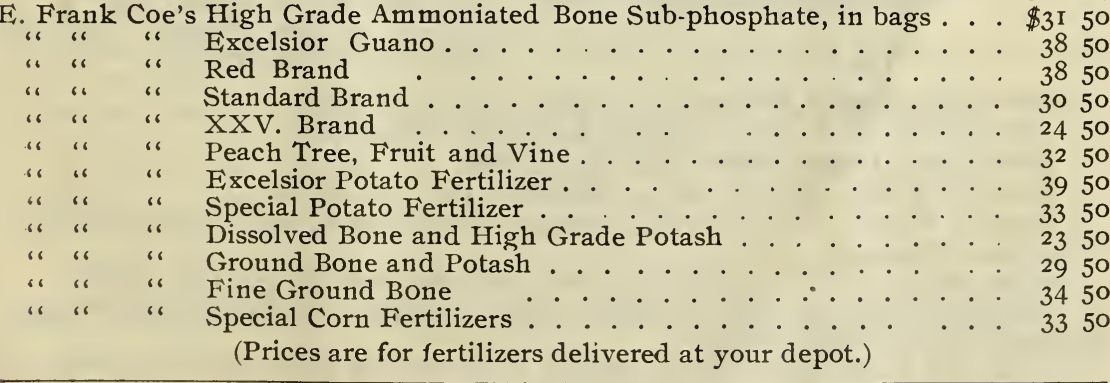

MR. T. J. DWYER,

FAIR OAKS, N. Y., Sept. I4th, I896.

Dear Sir-I rec'd the strawberry plants in good condition Sept. 10, I896, and fouud them to be very nice ones; thanking you for your prompt attention which you gave my order, I remain, Yours very truly, 


\section{VEGETABLE PLANTS.}

For the last three years we have made this a special feature of our business. Last year we disposed of over half a million plants, furnishing in many instances 25,000 celery plants to a single party. As we have a very large area under hot-bed sash, our facilities for growing good, healthy plants are unsurpassed, and as we have been extensively engaged in the market gardening, we are enabled to give advice as to the best valieties. We would like an opportunity to figure on any large order for any variety of vegetable plants named below.

\section{CELERY PLANTS-(TRANSPLANTED). \\ (Ready May 2oth.)}

We will furnish any of the varieties named hereafter, fine, strong, transplanted plants, at 50 cents per $100 ; \$ 4.00$ per 1,000 .

Write us for prices on large lots of $5,000,10,000$ or upwards.

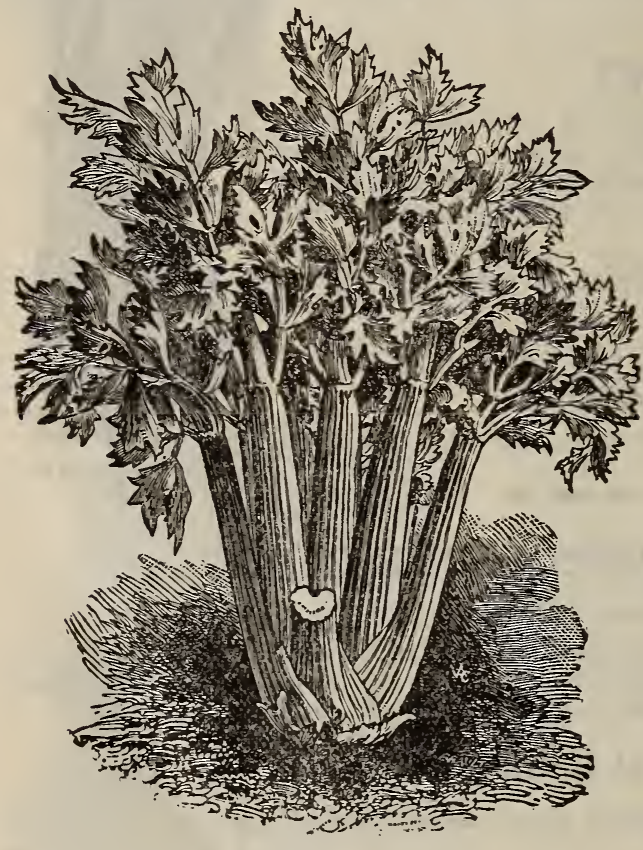

GIANT PASCAL.

\section{VARIETIES.}

Giant Pascal, Golden Dwarf, New Rose, Lundon Red, Half Dwarf, White Plume, White Walnut, Boston Market, Golden Self-Blanching, Perfection Heartwell, Large White, Early Arlington.

Any of the above varieties, not transplanted, but good, strong plants that have been shorn off, at 35 cents per $100 ; \$ 2.50$ per I,000.

12.85 These prices include careful packing in moss.

\section{CABBAGE, TOMATO, letTUCE, \&C.}

\section{(Ready May Ist.)}

Please remember the prices asked are for all strong transplanted plants of all the vegetables named below.

Early Cabbage Plants-Winnıgstadt, Early, Flat Dutch, Brunswick, Succession, Henderson's Early Summer, Jersey Wakefield, Early York.

Per 25, 20 cents; per 50, 40 cents; per I00, 70 cents; per 1,000 $\$ 5.00$; per $5,000, \$ 20.00$.

Early Cauliflower Plants-Henderson's Early Snow Ball. Price per dozen, 20 cents; per I00, $\$ 1.00$; per I,000, $\$ 8.00$.

Extra Early Dwarf Erfurt-Half Early Paris.

Price per dozen, I5 cents; per I00, 80 cents; per I,000, $\$ 6.00$.

Lettuce Plants-Boston Market, Deacon, All the Year Round, Henderson's N.Y. Black Seeded Simpson.

Price, per 25,20 cents; per 50,40 cents; per 100, 70 cents; per I,000, $\$ 6.00$.

Tomato Plants-Dwarf Champion, Acme, Perfection, General Grant, Trophy, Paragon, Mikado, Early Ruby.

Price per 15,25 cents; per 25,35 cents; per 50, 60 cents; per 100, $\$ 1.00$; per I, $000 . \$ 8.00$; for strong transplanted plants.

We have in the above varieties, strong, vigorous pot-grown plants at 40 cents per dozen ; per 25, 70 cents; per 50, $\$ 1.00 ;$ per 100, $\$ 1.75$. These are very desirable plants for those who wish Extra Early Tomatoes. 
Pepper Plants-Large Bell, Sweet Mountain.

Price per dozen, 35 cents; per Ioo, $\$ 1.00$.

Egg Plants-N. Y. Improved Purple, Black Pekin.

Price per dozen, 30 cents ; per 50, $\$ 1$.00; per Ioo, $\$ 1.75$.

We have any of these varieties of Pepper and Egg Plants grown in pots at 50 cents per dozen ; 8o cents per $25 ; \$ 1.50$ per $50 ; \$ 2.50$ per 100 .

\section{ORNAMENTAL DEPARTMENT.}

\section{WEEPING TREES.}

Weeping Mountain Ash, Kilmarnock Willow, Cut-Leaved Birch, European Ash. Price for above trees, five to seven feet, $\$$ I.0o each; $\$ 10.00$ per dozen.

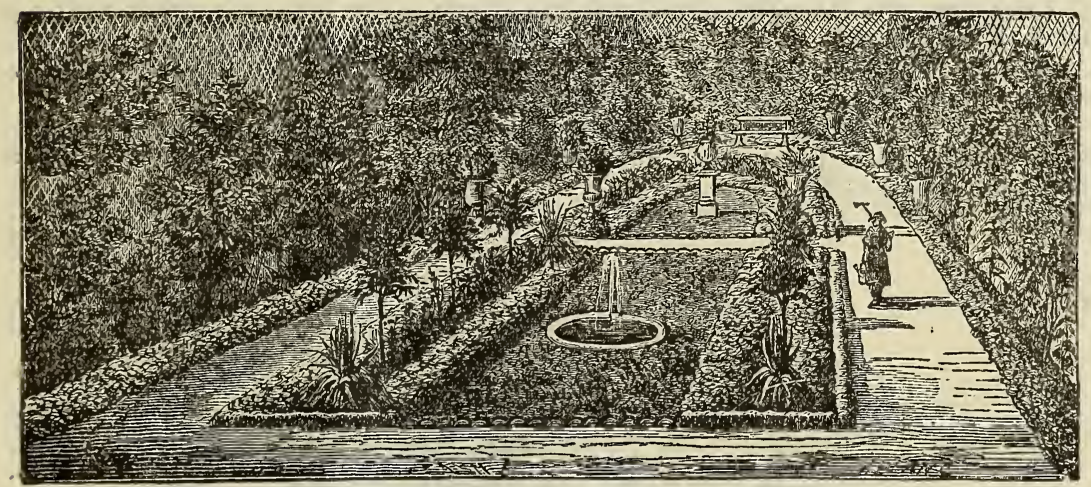

\section{UPRIGHT DECIDUOUS TREES.}

Ash, Black-A fine, vigorous growing tree.

Ash Whife-A rapid growing native tree for planting on streets or in parks.

Birch-Purple Leaved-A desirable novelty, with the habit of birches. It has beautiful foliage.

Catalpa-A variety originating in the west; more symmetrical in growth than the common Catalpa.

Catalpa Teas, Japanese Hybrid-Of vigorous, upright growth. Has large, luxuriant foliage, with a large, bandsome white flower.

Horse Chestnut, Double White Flowering.-A superb variety, with large double flowers.

Horse Chestnut, Red Flowering-Not so rapid a grower as the white; foliage of dark green, and blooms later. A very showy tree.

Mountain Ash, European-A fine, hardy tree; head dense and regular.

Mountain Ash, Oak-Leaved-A variety with very large leaves; distinct and fine; beautiful for park or meadow.

Linden, European-A pyrimidal tree, with large leaves and fragrant flowers.

Linden, American-A rapid growing, beautiful, native tree, with very large leaves and fragrant flowers; fine for street planting, giving quick shade in spring.

Malpe, Ash-Leaved-A fine, rapid growing variety, very hardy and excellent for avenues.

Black Walnut-A very desirable, handsome tree.

Maple, Norway-A distinct foreign variety, with large, broad leaves of a deep rich green. 
Maple, Scarlet-A rapid growing tree, with red flowers in early spring.

Maple, Silver-Leaved-An excellent shade tree of rapid growth; are desirable for immediate effect.

Maple, Sugar-A very popular tree, both for lawns and avenues; it is symmetrical in growth.

Maple, Weir's Cut-Leaved-A silver maple, with remarkable and beautiful dissected foliage ; of rapid growth ; shoots slender and drooping, giving it a very graceful appearance; should be in every collection.

Japan Magnolia-A new tree of great beauty and medium height. Flowers large and fine, creamy white, very fragrant; blooms in June, after foliage has developed.

Tulip Tree-Golden variegated leaf. This is a very desirable tree, and should have a place on every lawn.

Poplar, Vn Geert's Golden-This tree has fine golden yellow foliage which retains its brilliancy throughout the season.

Carolina-This is perhaps the largest of all the native Poplars, suitable for street and park plantings.

Beech, Purpel-Leaved-Resembles the American in habit and rapidity of growth The foliage is of dark purple or chocolate color.

Price of any of the above named first-class trees, ranging in size from 5 to 8 feet, 75 cents each; $\$ 6.00$ per dozen. Any variety named, in large sizes from $S$ to ro feet, $\$ 1.25$ each; $\$ 12$ a dozen.

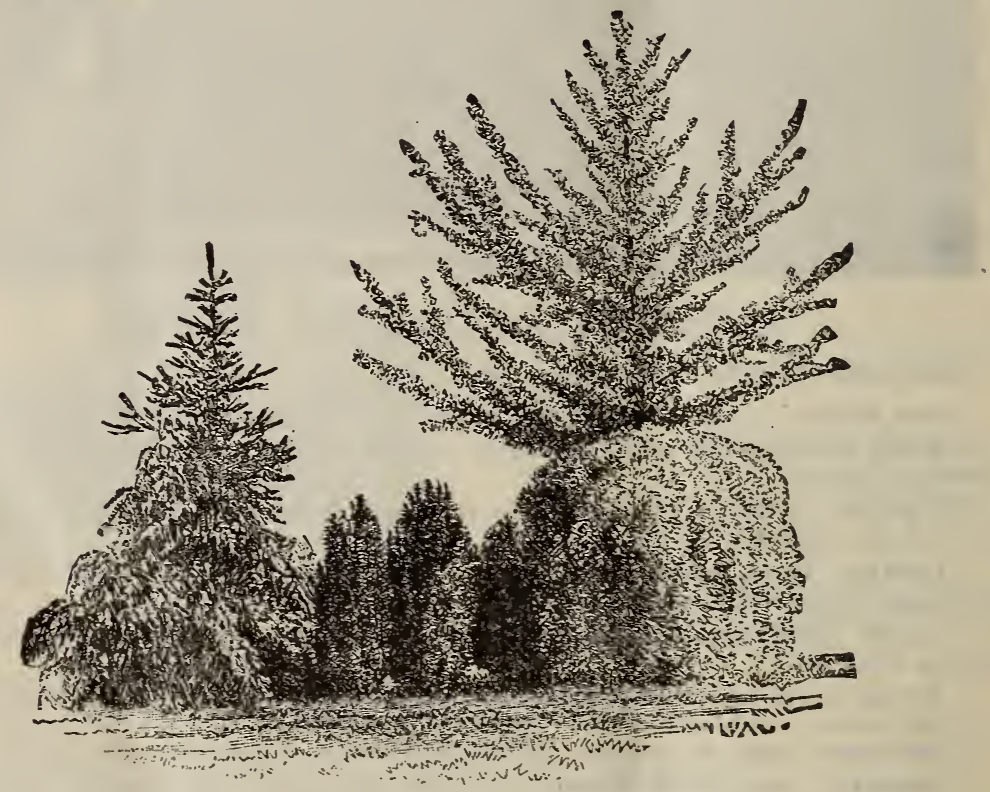

\section{EVERGREEN TREES.}

This is a careful selection of varieties which will do well in all parts of the country.

Arbor Vitæ (American).-One of the most desirable evergreen hedge-plants. Of very attractive appearance. Although a fast grower it can be kept trimmed to any height desired.

Price, 2 to 3 feet, 30 cents each; $\$ 3.00$ per dozen; $\$ 22$ oo per hundred. 3 to 4 feet, 40 cents each; $\$ 4.00$ per dozen; $\$ 30.00$ per Ioo. 4 to 5 feet, 50 cents each; $\$ 5.00$ per dozen $\$ 40.00$ per 100 . 
Spruce-(Norway).-A popular variety. Makes a very dense, compact hedge. Very desirable for a firm hedge, to take the place of a fence.

Price for trees 2 feet in height, 30 cents each; $\$ 3.00$ per dozen; $\$ 20.00$ per roo. 3 to 4 feet, 40 cents each; $\$ 4$ oo per dozen; $\$ 30$ per hundred. 4 to 5 feet, 75 cents each; $\$ 6.00$ per dozen; $\$ 50.00$ per Ioo.

White Spruce-Compact pyramidal form, of greater symmetry than that of the Norway Spruce. Tree very hardy.

Price, 3 to 4 feet, 50 cents each; $\$ 5$.0o per dozen. 4 to 5 feet, $\$ 1$.oo each; $\$ 10.00$ per dozen.

Colorado Blue Spruce-A magnificent variety of the spruce; of compact growth, with strong, handsome foliage of a blue shade.

Price for trees, 2 to 3 feet, 75 cents each; $\$ 7.50$ per dozen. 3 to 4 feet, $\$ 1$.oo each ; \$10.00 per dozen.

Spruce (Hemlock).--Very fine, graceful and ornamental, with fine, smooth, rich foliage, making a beautiful hedge, but not as strong a one as the Norway. It is especially graceful.

Price 2 to 3 feet, 75 cents each ; $\$ 7.00$ per dozen ; $\$ 50.00$ per Ioo. 3 to 4 feet, $\$$ r.co each; $\$ 8.00$ per dozen; $\$ 60.00$ per 100 .

\section{BOX.}

Box Tree Common-Spherical form of great symmetry; foliage of deep, rich, glossy green color. Very ornamental.

Price, I to $21 / 2$ feet, each, 25 cents.

Retinospora-A very hardy species of graceful habit, with fine, delicate green foliage. One of the best and most hardy.

Price, 2 to 3 feet, each, 50 cents ; 3 to 4 feet, each, 75 cents.

Irish Juniper-Very erect and tapering in its growth, forming a column of deep green foliage; a pretty little tree or shrub, and for its beauty and hardiness is a general favorite.

Price of trees, 2 to 3 feet, each, 50 cents ; 3 to 4 feet, each, 75 cents.

\section{PINES.}

All of these are extremely hardy, and they can be depended upon to grow in the most exposed situations.

Austrian or Black-A very remarkably robust, hardy, spreading tree; leaves long, stiff and dark green ; growth rapid ; valuable for this country.

Dwarf Mountain-A low, spreading, curious species, attaining only the size of a bush. Foliage similar to that of the Scotch.

Scotch-A nine robust, rapid growing tree, with stout, erect șhoots, and silvery green foliage.

American White-The most ornamental of all our native pines. Foliage light, delicate and silvery green. Flourishes in the poorest soils.

Price, for any of the above varieties, 2 to 3 feet, each, 30 cents; per dozen, $\$ 3.00$; per hundred, $\$ 22.00 ; 3$ to 4 feet, each, 40 cents; per dozen, $\$ 4.00$; per hundred $\$ 30.00$.

\section{DWARF ARBOR VITAES.}

The four varieties noted below are of dwarf habit, and all have very beautiful foliage.

Geo. Peabody-Very hardy, beautiful and showy, of dwarf, compact habit; foliage of a rich. bright golden color.

Siberian-Exceedingly hardy, of rather slow growth, conical form, compact and symmetrical. 
Globe-Very dense and dwarf, forming a round ball without any trimming or training, distinct, hardy and popular.

Hovey's Golden-Of dwarf habit, globular form, dense growth, foliage of a live1y yellowish green.

Price of any above varieties, 18 to 24 inches, each, 50 cents; per dozen, $\$ 5.00$.

\section{Berry Crates, Baskets, Etc.}

We can furnish any of the Berry Crates, Baskets, Cups, etc., at the prices named below, which are very low for the stock, which is made here, and is strong and durable. (We cannot allow any discount on these prices.)

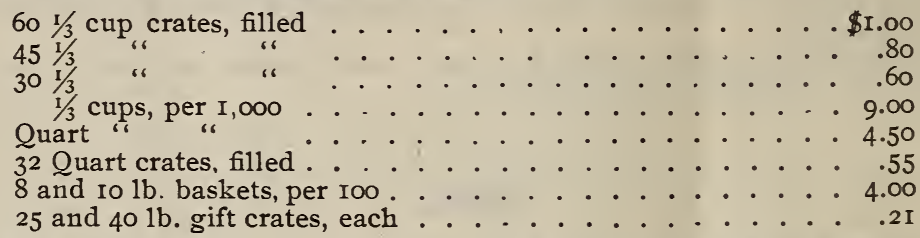

Please note, that we will allow you a discount of ten per cent. on all orders (collections excepted) to the amount of $\$ 1.00$ and upward, providing the same reaches us by March 15 .

\section{FLOWERING SHRUBS. ALMOND.}

Double Pink-A beautiful small shrub, bearing in the spring before the leaves appear, an abundance of small, double, rose-like flowers, closely set on a twig.

Double White-Similar to the pink, flowers pure white, very beautiful.

Price of above, each 40 cents ; per dozen, $\$ 4.00$.

\section{ALTHAEA OR ROSE OF SHARON.}

Double Blue, Double Purple, Double Red, Double Variegated, Double White.

Price of above, 40 cents each ; $\$ 4.00$ per dozen.

\section{BARBERRY.}

Purple-Violet-colored foliage and fruit; rich looking and very effective when contrasted with plants of lighter foliage.

Thunbergh-A desirable Japan variety of dwarf habit. Small foliage changing to beautiful red in autumn.

Price of above, 40 cents each; $\$ 4.00$ a dozen.

\section{DEUTZIA.}

Crenata-A medium-sized shrub, which bears a profusion of pink and white flowers; very pretty.

Double White-Similar to the above, with pure white flowers, and of more spreading habit.

Price of above, 40 cents each; $\$ 4.00$ per dozen. 


\section{DOGWOOD.}

Variegated-A distinct and attractive variegated foliage. Small yellow flowers in early spring, succeeded by scarlet berries in autumn.

Red Twigged-This variety has brighter red twigs than any other sort, and is highly esteemed for the showy effect it produces in a shrubbery collection.

Price of above, 40 cents each; $\$ 4.00$ per dozen.

\section{HYDRANGEA.}

New Japan-This is one of the most showy shrubs in cultivation, with beautiful, hardy foliage, and great pyramidal panicles of white flowers more than a foot long, which change to pink. Very ornamental, from mid-summer until destroyed by frost. Should be in every yard.

Price of above, 40 cents each; $\$ 4.00$ per dozen.

\section{LILAC.}

Common-The common purple species and one of the best.

Common White-Flowers pure white; fragrant; beautiful.

Josika's-Deep lilac flowers. A choice, late-blooming variety.

Price of above, each, 40 cents ; per dozen, $\$ 4.00$.

\section{MOCK-ORANGE.}

Double Flowering-Desirable for its beautiful double white flowers.

Golden-Leaf-A new variety, with bright yellow foliage; one of the most desirable and effective yellow leaf shrubs.

Price of above, each 40 cents ; per dozen, $\$ 4.00$.

\section{SPIRAEA.}

Prunifolia Flora Plena (Bridal Wreath.) --Strong-growing, irregular form, small, roundish, shining leaves, of beautiful autumn color; flowers double, white; abundant in May.

Van Houttel-An upright growing shrub, with graceful, slender branches and bright green foliage, rather curiously lobed. The flowers, of pure white, are in great. clusters.

Price of above, each 40 cents; per dozen $\$ 4.00$.

\section{JAPAN SNOWBALL.}

A beautiful flowering shrub; the flower clusters, which are produced all over the bush, are spherical in form, and of the purest white, with dark green foliage.

Price, first-class, each, 40 cents; per dozen, $\$ 4.00$.

\section{RHODODENDRONS.}

Album Elegans. - Very large, white.

Brandyanum.-Bright cherry.

Candidissimum.-Pure white.

Everestianum.-Rosy lilac, crimped, good form.

Gigante um.--Large, rosy crimson.

Gloriosum, Waterer's. -Large blush. 
Grandiflorium.-Rosy crimson, one of the best.

Purpureum Elegans.-Fine purple.

Price, I2 to I8 inches, each, $\$$; per dozen, $\$ 10 ;$ I8 to 24 inches, with 3 to 6 flower buds, each, $\$ 2$; per dozen, $\$ 20$.

\section{HARDY ROSES. HYBRID PERPETUAL ROSES.}

Anne De Diesbach.-Carmine, a beautiful shade, very large. A superior garden sort, fragra nt, one of the hardiest. Budded and on own roots, each $50 \mathrm{cts}$.

Annie Wood.-Vermillion, very fragrant, fine in Autumn, of splendid finish. Budded plants, each, 50 cents.

Baroness Rothschild.-Light pink, cupped form, very symmetrical iwithout fragrance. Very distinct and beautiful. Budded plants, each $50 c$.

General Jacqueminot.-Brilliant crimson, not full, but large and extremely effective, fragrant. On own roots, each, 50 cents.

General Washington.-Bright red, with crimson shade, large, flat form, often indented or imperfect. Budded and on own roots, each, 50 cents.

John Hopper-Bright rose, with carmine center; large and full. A profuse bloomer and standart sort. Budded and on own roots, 50 cents.

Marshal P. Wilder-Flowers large, semi-globular, full, well formed; color cherry carmine. Each 50 cents.

Mrs. John Laing-Soft pink; large and of fine form, produced on strong stems, exceedingly fragrant. Budded and on own roots, 75 cents.

Paul Neyron-Deep rose color; good, tough foliage; wood rather smooth. By far the largest variety in cultivation. Budded and on own roots. Each 50 cents.

Magna Charta-A splendid sort; bright, clear pink, flushed with violet-crimson; very sweet, flower extra large, fine form, very double and full, a free bloomer. Price 50 cents.

\section{CLIMBING OR PRAIRIE ROSES.}

Anna Maria-Blush, cluster large, has few thorns. On own roots. Price 50 cents.

Baltimore Belle-Pale blush, becoming nearly white; compact and fine. On own roots, price 50 cents.

Gem of the Prairies-Red, occasionally blotched with white. Large, flat flowers. The only variety in the class that is fragrant. Budded plants, price 50 cents.

Mrs. Hovey-Pale, delicate blush, becoming almost white; resembles Baltimore Belle. On own roots. Price 50 cents.

Queen of the Prairies. - Bright, rosy red, frequently with white stripe. On own roots. Price 50 cents.

Triumphant-White, tinted with flesh, double and compact, distinct. On own roots. Price 50 cents.

\section{HARDY CREEPING VINES. AMPELOPSIS VEITCHII.}

(BOSTON OR JAPAN IVY).

One of the finest of Ornamental climbers. It clings firmly to stone, brick or wood, in fact to buildings of any material, and is entirely hardy. Foliage small. Fine strong plants. Price, each, 40 cents; per dozen, $\$ 4.00$. 


\section{VIRGINIA CREEPER.}

A variety well known and appreciated; of luxurious, vigorous growth, and owing to its ivy-like tendrils, valuable for covering unsightly objects. Price, each, 50 cents ; per dozen, $\$ 3.00$.

\section{DUTCHMAN'S PIPE.}

Yellowish brown flowers in July. When trained on a trellis, very effective in forming a screen. Price, each, 40 cents ; per dozen, $\$ 4.00$.

\section{CLEMATIS.}

Jackmanni-The pioneer of the large flowered, improved clematis, and with few, if any equals, and no superiors. Vigorous, perpetual, very profuse and constant. Flowers large. Price, each, 75 cents ; per dozen, $\$ 8.00$.

Jackmanni Alba-Similar to the preceding in all respects, except that the flowers are pure white. Strong, $\$ 1.00$.

Henryi-One of the best of the lanuginosa type, and the best white clematis. Flowers occasionally during summer and early autumn. Price, $\$ 1.00$ each.

\section{HONEYSUCKLE.}

Hall's Japan-An almost evergreen honeysuckle of the greatest value, being entirely hardy, and of strong, vigorous growth. The flowers are exceedingly fragrant, of pure white, changing to yellow. Plants, each, 30 cents ; per dozen, $\$ 3.00$.

Japan Golden-Veined-A beautiful variety, of moderate growth, with foliage exquisitely veined and netted with golden yellow lines. Flowers large and peach colored, each, 25 cents; per dozen, $\$ 2.50$.

Monthly Fragrant-Showy flowers of red and yellow, delightfully fragrant, continues to bloom a long time. June and July. Each, 25 cents; per dozen, $\$ 2.50$.

\section{WISTARIA.}

Chinese Blue-The flowers are of a pale blue color, and are borne in pendulous racemes in May and June. Large, each, 35 cents.

Chinese White-Very like the Chinese Blue, except that the flowers are white and remain longer. Each, 50 cents.

Please note that we will allow you a discount of ten per cent. on all orders (collections excepted) to the amount of $\$ 1.00$ and upwards, providing the same reaches us by March 15 th.

\section{CALIFORNIA PRIVET HEDGE.}

This makes a very desirable plant for hedging purposes. It is a very rapid grower, and thrives well on poor land. It makes a beautiful hedge and remains green throughout the year, thus making it an evergreen. On account of its adaptability to poor land and unfavorable situations, it has become very popular.

Price, 2 to 3 feet, stocky plants, per dozen, $\$ 1.00$; per I00, $\$ 500$; per r,000, $\$ 40.00$. Price, 3 to 4 feet, heavy stocky plants, each, I5 cents; per dozen, $\$ 1.25$; per 100. $\$ 9.00$. Price 4 to 5 feet, large selected plants, three and four years old, each, 25 cents; per dozen, $\$ 2.50$; per 100, $\$ 16.00$. 


\section{TABLE OF CONTENTS.}

Almond

PAGE

Althæa

Ampelopsis Veitchii

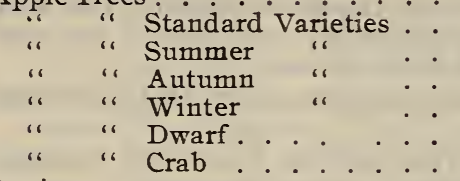

Apricot . . . . . . .

Arbor Vitæs, Dwarf . . . . . . 47

Asparagus .. . . . . . . 42

Barberry . . . . . . . . 48

Blackberries . . . . . . . I8

BoxTrees . . . . . . . . 47

Cabbage .......... . 44

Cauliflower ......... . 44

Celery Plants . . . . . . . . . 44

Cherry Trees . . . . . . . . . 37

" " New Varieties . . . 37

" " Standard Varieties . 37

Clematis ......... . 5 I

Crates, Baskets, etc. . . . . . . 48

Creeping Vines . . . . . . . . 50

Currants ......... . 20

Deciduous Trees . . . . . . 45

Dewberries . . . . . I8

Deutzia . . . . . . . . 48

Dogwood . . . . . . . 49

Dutchman's Pipe . . . . . . 5 I

Egg Plant ...... . 45

Evergreen Trees . . . . . 46

Family Lists . . . . . . 2

Fertilizers-E. Frank Coe's . . 43

Price List . . . . . . 43

Flowering Shrubs. . . . . . 48

Garden Roots. . . . . . . . 42

General Instructions . . . . . . . I

Gooseberries . . . . . . . 23

Grapes . . . . . . . . 24

Hedge, California Privet . . .

Honeysuckle . . . . . . . 5 I

Horseradish ... . . . . 43

Hydrangea . . . . . . . . 49

Juneberry . . . . . . . I I3

Location . . . . . . Second cover

Lettuce . . . . . . . . 44

Lilac ......... . . 49

Mulberries ........ $4 \mathrm{I}$
Mock Orange. . . . . . . . 49

Nut Trees ...... $4 \mathrm{I}$

Ornamental Department . . . 45

Pear Trees ....... 30

" " New Varieties . . . 3 I

“ "

" " " Autumn ". . 33

" " "Winter " . . 34

" " $"$ Standard Varieties .. $\quad 32$

" “ (Dwarf) . . . . 34

"Well Known Varieties 34

" " Standard Varieties. 35

Pines . . . . . 35

Plants by Mail . . . . . . 2

Plum Trees......... . 38

" "Japan Varieties . . . . 38

Pepper Plants " European Varieties . . $\quad 39$

Pot Grown Plants. . . . . . . . 45

Quince Trees ....... 40

Radish, Horse . . . . . . . . . 43

Raspberries, Red ....... I3

References . . . Sa Second cover

Rhubarb ........ . 43

Rhododendrons . . . . . . . 49

Roses, Hardy. . . . . . . . 50

“ Hybrid Perpetual . . . . 50

" Climbing ....... 50

Shipping Directions . . . . . . I

Snowball, Japan . . . . . . . 49

Stra wberries, How to Plant . . . . 3

Pot Grown . . . . II

Not Grown Varieties : * $\quad$ II

Standard Varieties . IO

Additional Varieties II

Strawberry-Raspberry . . . . I2

Summer Catalogue . . . Third cover

Spiræa .. . . . . . 49

Substituting . Second cover

Telegraph Office . . . . Second cover

Terms .......... I

Testimonials . . . Third cover

Tomato Plants . . . . . . . 44

Vegetable Plants . . . . . . 44

Virginia Creeper . . . . . . 51

Wineberries, Japan . . . $\quad \ldots \quad 22$

Wistaria ........ 5 I

Weeping Trees ...... 45 


\section{OUR SUMMER CATALOGUE}

of pot grown and ground layer strawberry plants, celery, cabbage and cauliflower plants will be sent out about June 15. All the new varieties of strawberries that have been fruited at the Orange County Nurseries and found valuable will be listed therein, with full and accurate descriptions. In this list we will offer 50,000 potgrown strawberry plants that we have ready for shipment every week during the months of July, August, September and October, also the layer strawberry plants in unlimited quantities. We will fruit over fifty varieties of the strawberry the coming season, both of the old and new kinds. All of these will be offered for sale at prices that cannot be reduced for the same quality of stock.

In this catalogue we will also offer some fifteen or more varieties of the best and most profitable celery plants, with descriptions and illustrations of some of the leading sorts. The growing of celery plants has become a very important part of our business. We can always quote a special low figure on lots of 5,000 plants and upwards.

\section{A Few Testimonials.}

The following testimonials have been received during the season of 1896 . They come to us unsolicited, and as you may observe are from very prominent men. Parties who are in the habit of receiving the best. They have been pleased with our gonts. We think we can also please you and request that you send us a trial orde1.

T. J. DWYER,

“'Ferncliff," RHINeBeck, N. Y., Sept. Ioth, I8g6.

Sir-The strawberry plants arrived all O. K. and in first-class condition. Send Asparagus Roots as soon as you can (next week), and oblige

Yours truly,

Manager for Hon. J.J. Astor.

HORACE DEAL.

T. J. Dwyer, Esq., Cornwall, N. Y.,

H. MCK. TwомBLY, Madison, N. J., Aug. 26, I896.

Dear Sir-The strawberry plants arrived in very good order. Mr. Herrington, the head gardner, makes a very satisfactory report, saying, that they are the best lot we have ever received.

Yours very truly,

E. BURNETT, Manager.

T. J. DWYER,

WARWICK, Nov. 16, I8g6.

Dear Sir-Your 400 apple trees shipped to me came to hand Thursday noon, and as it rained Thursday afternoon and Friday I did not unpack them until to-day, Saturday, or I should have sent the money before, as the trees are perfectly satisfactory.

Yours respectfully,

H. P. DEMAREST.

Address all communications to

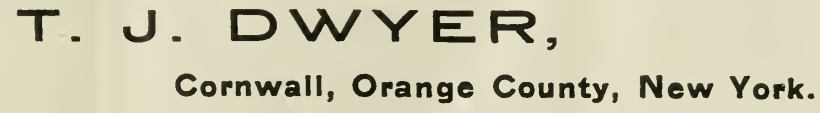




\section{CATALOGUE}

\section{Orange County Nurseries.}

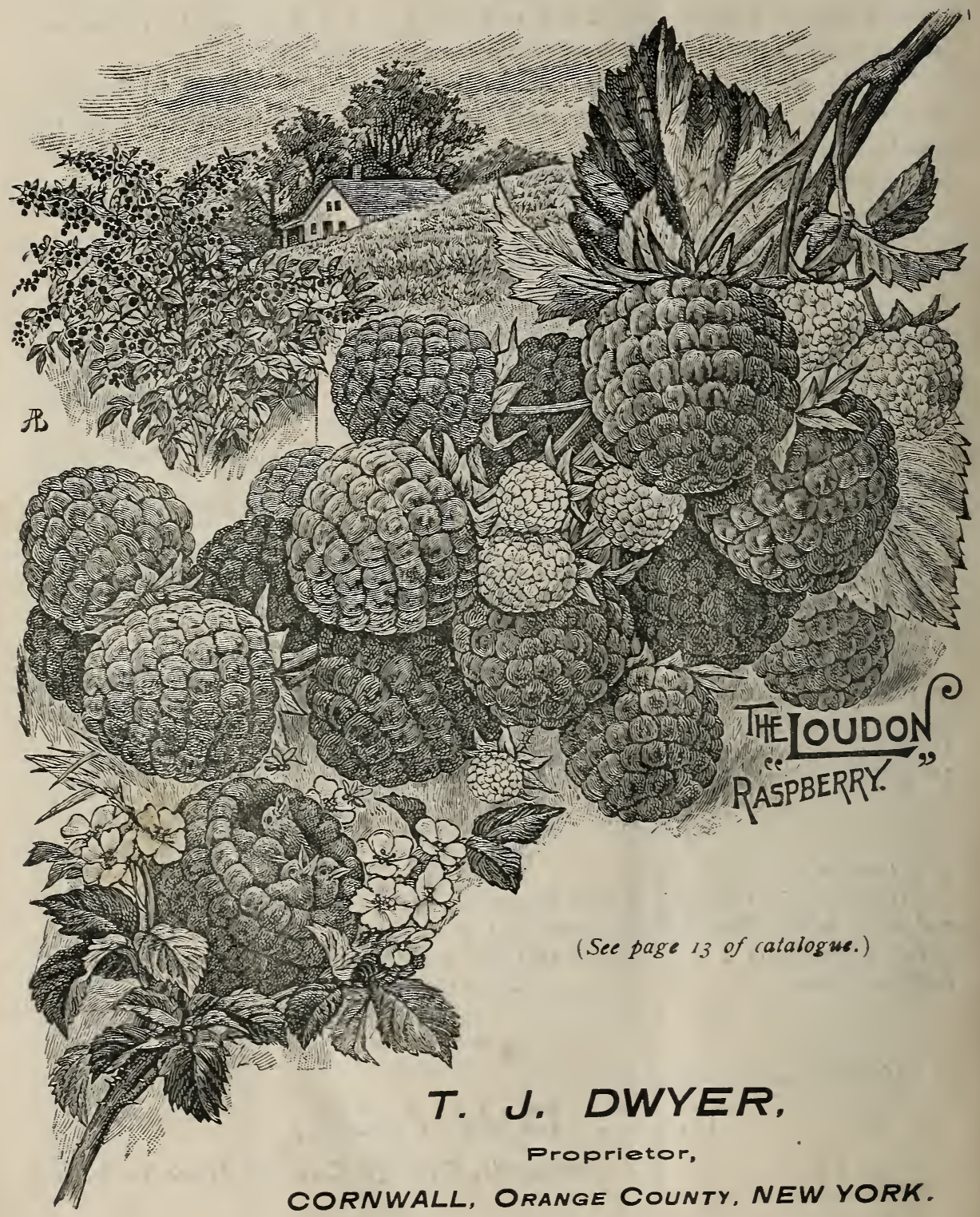

